\title{
Different gene response to mechanical loading during early and late phases of rat Achilles tendon healing
}

Malin Hammerman, Parmis Blomgran, Arie Dansac, Pernilla T. Eliasson and Per Aspenberg

The self-archived postprint version of this journal article is available at Linköping University Institutional Repository (DiVA):

http:// urn.kb.se/ resolve?urn=urn:nbn:se:liu:diva-143094

N.B.: When citing this work, cite the original publication.

Hammerman, M., Blomgran, P., Dansac, A., Eliasson, P. T., Aspenberg, P., (2017), Different gene response to mechanical loading during early and late phases of rat Achilles tendon healing, J ournal of applied physiology, 123(4), 800-815. https:/ / doi.org/ 10.1152/japplphysiol.00323.2017

Original publication available at:

https:/ / doi.org/ 10.1152/ japplphysiol.00323.2017

Copyright: American Physiological Society

http:// www.the-aps.org/ 
Title:

Different gene response to mechanical loading during early and late phases of rat Achilles tendon healing

\title{
Running head:
}

Gene response after loading in healing tendons

\section{Authors:}

M. Hammerman, P. Blomgran, A. Dansac, P. Eliasson, and P. Aspenberg

\begin{abstract}
Affiliation:
Orthopedics, Department of Clinical and Experimental Medicine, Faculty of Health Science, Linkoping University, Sweden
\end{abstract}

\section{Corresponding author:}

Malin Hammerman

malin.hammerman@liu.se

Phone: +46101034116

Address: Linköpings universitet

Ortopedi, IKE, KEF, plan 9, US

58185 Linköping 


\section{Author contributions:}

Conceived and designed the experiments: M.H., P.E. and P.A. Performed the experiments: M.H., P.B., and A.R. Analyzed the data: M.H. and A.R. Drafted the manuscript: M.H. Edited and revised the manuscript: M.H., P.B., P.E., A.R., and P.A.

\section{Keywords:}

tendon healing, gene expression, inflammation, mechanical loading 


\begin{abstract}
Mechanical loading stimulates tendon healing both when applied in the inflammatory phase and in the early remodeling phase of the process, although not necessarily via the same mechanisms. We investigated the gene response to mechanical loading in these two phases of tendon healing. The right Achilles tendon in rats was transected and the hind limbs were unloaded by tail suspension. The rats were exposed to 5 minutes of treadmill running 3 or 14 days after tendon transection. Thereafter, they were re-suspended for 15 minutes or 3 hours until euthanasia. The controls were suspended continuously. Gene analysis was first performed by microarray analysis followed by qRT-PCR on selected genes, focusing on inflammation. 15 minutes after loading, the most important genes seemed to be the transcription factors EGR1 and C-FOS, regardless of healing phase. These transcription factors might promote tendon cell proliferation and differentiation, stimulate collagen production, and regulate inflammation. 3 hours after loading Day 3, inflammation was strongly affected. Seven inflammation-related genes were upregulated according to PCR; CCL20, CCL7, IL-6, NFIL3, PTX3, SOCS1, and TLR2. These genes can be connected to macrophages, T cells, and recruitment of leukocytes. According to Ingenuity pathway analysis, the recruitment of leukocytes was increased by loading Day 3 which also was confirmed by histology. This inflammation-related gene response was not seen Day 14 . Our results suggest that the immediate gene response after mechanical loading is similar in the early and late phases of healing, but the late gene response is different.
\end{abstract}




\section{New \& Noteworthy}

This study investigates the direct effect of mechanical loading on gene expression during different healing phases in tendon healing. One isolated episode of mechanical loading was studied in otherwise unloaded healing tendons. This enabled us to study a time sequence, i.e. which genes were the first ones to be regulated after the loading episode. 


\section{Introduction}

Tendons adapt to mechanical loading (25, 31, 39, 47, 60). Tenocytes register mechanical load or deformation via mechanotransduction, leading to changes in gene and protein expression $(11,13$, 25, 31). The changes can lead to increased matrix production, including increased expression of collagens, thus enabling the tendon to cope with increased loading (13, 25, 31, 47, 60).

Mechanical loading is also important during tendon healing (3, 7, 25, 31, 47, 52). A loaded healing tendon becomes several-fold stronger, with better material properties, compared to unloaded healing tendons $(2,3,22)$. As little as 5 minutes of daily mechanical stimulation is sufficient to improve Achilles tendon healing in rats (23). The underlying mechanisms have not been clarified. However, mechanical loading induces changes in gene expression in healing tendons $(7,22,31)$. We have previously shown that a single loading episode in an otherwise unloaded healing tendon, 5 days after injury, alters the gene expression pattern (23). 5 genes were up-regulated already 15 minutes after loading, and 4 of these were transcription factors. Interestingly, one of the transcription factors, early growth response 1 (EGR1), has been shown to be important for tendon development and promotes tendon repair $(26,28,34)$. 3 hours after loading, 150 genes were regulated, including genes involved in inflammation, wound healing, apoptosis, cell proliferation, cell differentiation and extracellular matrix remodeling (21).

Tendon healing can be divided into three overlapping phases; inflammation, proliferation and remodeling $(25,31)$. Contrary to what has been believed, mechanical loading has a stimulatory effect not only during the early remodeling phase but also when applied during the inflammatory phase $(2,20)$. Although beneficial in both phases, the mechanism might be different, because the 
cellular and matrix composition of the loaded region is different $(25,31,41)$. In the inflammatory phase, the healing tissue contains a high proportion of inflammatory cells, and a loose fibrous stroma, rich in collagen type III $(6,25,31,41)$. Later, in the early remodeling phase there is a denser connective tissue dominated by collagen type I together with fibroblast or tenocytes and few inflammatory cells $(6,25,31,41)$.

To better understand how mechanical loading improves tendon healing, we now studied the gene expression in healing tendons during different phases: the inflammatory phase and the early remodeling phase. To understand the specific effects of loading, we studied isolated episodes of loading in otherwise unloaded tendons, which enables us to study a time sequence of regulated genes. In contrast, a comparison of animals that have been continuously loaded or unloaded would just have shown the gene expression pattern far down-stream of loading, i.e. genes that are associated with the consequences of loading, such as a stronger and thicker tendon.

This report describes the gene expression pattern after a single loading episode in the inflammatory and early remodeling phase of tendon healing, i.e. 3 or 14 days after injury, respectively. The immediate gene response, 15 minutes after loading, and the late gene response, 3 hours after loading, were studied using microarray and quantitative real-time PCR (qRT-PCR). The general hypothesis was that the response to loading would be different during different phases of the healing process, especially regarding inflammation-related genes. 


\section{Materials and Methods}

\section{Study design}

82 female Sprague-Dawley rats (10-12 weeks old) were used for this study; 24 for microarray analyses ( $\mathrm{N}=4)$, 33 for qRT-PCR analyses $(\mathrm{N}=4-7)$, and 8 for histology $(\mathrm{N}=4) .17$ rats had to be excluded; 12 because they had fallen down from the tail suspension device, 4 because they had chewed on their wounds, and 1 rat was excluded because the RNA extraction failed.

The right Achilles tendon of all rats was transected, and allowed to heal spontaneously. All rats were unloaded by tail suspension the day after transection. The rats were killed 3 or 14 days after transection. The controls were tail suspended continuously until euthanasia. The rats to be stimulated by mechanical loading were taken down from suspension and exposed to a single 5 minutes episode of loading by treadmill running on the day of euthanasia. For gene expression analyses, the rats were re-suspended for 15 minutes or 3 hours until they were killed for tissue harvesting. For histology, the rats were re-suspended for 3 hours until they were killed for tissue harvest (Figure 1).

All rats were randomized to the different groups by a lottery. Blinded evaluation was ensured by the fact that the samples had an identity number which could not be connected to a specific group during the whole analysis.

All experiments were approved by the Regional Ethics Committee in Linköping for animal experiments and adhered to the institutional guidelines for care and treatment of laboratory animals. The rats were housed one per cage and were given food and water ad libitium. 


\section{Surgery}

All rats were anesthetized with isoflurane gas (Forene, Abbot Scandinavia, Solna, Sweden) and given antibiotics (25 mg/kg, Oxytetracycline, Engemycin; Intervet, Boxmeer, The Netherlands) preoperatively. They were also given analgesics (0.045 mg/kg Buprenorphine, Temgesic; Schering-Plough, Brussels, Belgium) preoperatively and regularly until 48 hours after surgery. The surgery was performed under aseptic conditions. The skin over the right Achilles tendon was shaved and washed with chlorhexidine ethanol. A transverse skin incision was made lateral to the Achilles tendon, and the tendon complex was exposed. The plantaris tendon was removed. The Achilles tendon was transversely transected, and a 3 mm-segment was removed. The tendon was left to heal spontaneously without any sutures. The skin was closed by two stitches.

\section{Unloading}

One day after surgery, the hind limbs of all rats were unloaded by tail suspension. The tail suspension was carried out in special cages with an overhead system that allowed the rats to rotate and move in all directions using their forelimbs, whereas the hind limbs were lifted just above the cage floor. The rats had been acclimatized to the suspension cages before surgery. For suspension, an adhesive tape was attached to the rat's tail. The tape was connected to the overhead system by a fish-line swivel and a fish line. The tail suspension technique is described in more detail elsewhere (46).

\section{Mechanical loading}

The animals were either kept completely unloaded for the entire experiment or were subjected to a short, single loading episode, 3 or 14 days after tendon transection. During the loading episode, 
the rats were released from the suspension to walk on a treadmill for 5 minutes at $9 \mathrm{~m} / \mathrm{min}, 7.5^{\circ}$ uphill slope, before they were suspended again. The animals were monitored during the loading episode.

\section{Tissue harvesting}

66 rats were anesthetized with a subcutaneous injection $(0.5 \mathrm{mg} / \mathrm{kg}$ dexdomitor; Orion Pharma, Espoo, Finland; and Ketaminol, Intervet) while still suspended, and were taken down first when they were fully sedated. The corresponding unloaded controls were killed at the same time points. 58 rats were used for RNA extraction and harvested as follows during sedation. The skin was shaved and washed, and the healing tissue was dissected free of the surrounding soft tissue under aseptic conditions. Tissue harvest was timed to either 15 minutes or 3 hours after loading. A midpart segment from the healing tendon (consisting of newly formed tissue only) was harvested, quickly rinsed in sodium chloride, snap-frozen in liquid nitrogen, and stored at $-70^{\circ} \mathrm{C}$ until RNA extraction. The rats were thereafter euthanized with an overdose of pentobarbital sodium. The hind limbs were kept unloaded throughout the whole harvesting procedure. 8 rats were used for histology and harvested as follows, after euthanasia with carbon dioxide. The skin was shaved and the healing tissue was dissected free from the surrounding soft tissue. The healing Achilles tendon was taken out together with a small piece of the calf muscle (for orientation of the tissue) and placed on a silicone gel with two needles in purpose to keep the tendon straight.

\section{RNA extraction}


Extraction of RNA was carried out by a combination of the Trizol method and RNeasy total mini kit (QIAGEN, Sollentuna, Sweden). The tendons were kept frozen during homogenization and were pulverized one by one by a tungsten ball in liquid nitrogen-cooled vessels in a Retsch mixer mill MM 200 (Retsch, Haan, Germany). Trizol was added to the pulverized tendons and left to thaw at room temperature. Chloroform was added to the samples, followed by centrifugation and phase separation. The aqueous phase was transferred to new tubes containing $70 \%$ ethanol. RNA was further purified using the RNeasy total mini kit according to the manufacturers' instructions. Potential DNA contamination was eliminating by DNase treatment. RNA concentration and quality were analyzed with the Nanodrop ND-1000 spectrophotometer (NanoDrop Technologies, Wilmington, DE) and the RNA 6000 Nano kit (Agilent Technologies, Böblingen, Germany). RNA samples were stored at $-70^{\circ} \mathrm{C}$ until used.

\section{Microarray}

4 samples from each group were analyzed by rat microarrays (GeneTitan, Gene ST 1.1;

Affymetrix, Santa Clara, CA). The microarray (and the statistical analysis of the microarray) was carried out by the Bioinformatics and Expression Analysis (BEA) core facility at the Karolinska Institute, Stockholm. Differentially regulated genes were based on both fold change and the pvalue from a Student's t-test (RMA analyzed data) with a cutoff of $\geq 1.5$ or $\leq-1.5$ for fold change together with a p-value of $<0.05$. The Ingenuity Pathway Analysis software was used to assess the molecular and cellular functions from the microarray results from gene data obtained 3 hours after loading on both days. Only functions with an activation z-score of $\geq 2$ or $\leq-2$ and predicted upstream regulators with a p-value of $<0.05$ were considered. 


\section{Quantitative real-time PCR}

33 new samples, 4-7 rats in each group, were used to confirm selected genes from the microarray

analysis and $1.5 \mu \mathrm{g}$ of total RNA was transcribed into cDNA using a high-capacity cDNA reverse transcription kit (Applied Biosystems, United Kingdom). The cDNA was diluted in TrisEDTA buffer. 46 primers were used and purchased from Applied Biosystems (Life Technologies, Netherlands; Table 1). Amplification was performed in $15 \mu$ l reactions using TaqMan Fast PCR Master mix (Life Technologies, Great Britain) and each sample was analyzed in triplicate. Quantitative RT-PCR was conducted using the $\Delta \Delta \mathrm{C}_{\mathrm{t}}$ method and each sample was normalized to $18 \mathrm{~S}$ rRNA (Life technologies, Sweden). The down-regulated genes had a fold change between 0 and 1 and were converted to a negative value by this formula: $-1 /$ fold change. The efficiency for the normalizer (18S) and the target genes were all acceptable (slope $\leq 0.1$ ). The expression of the reference gene did not vary significantly between the groups. Reactions with no reverse transcription and no template were added as negative controls.

\section{Histology}

The tendons were fixed in 4\% phosphate buffered formaldehyde. After dehydration, the specimens were embedded in paraffin and sectioned parallel to the longitudinal axis of the tendon. One slide per specimen, comprising the full length of the healing tendon, was stained with Ehrlich hematoxylin and eosin. Two more slides were stained for CD45 ${ }^{+}$cells (leukocytes) and $\mathrm{CD}^{+} 8^{+}$cells (macrophages) detected by immunoperoxidase staining as follows. For antigen retrieval, citrate buffer was used for $1 \mathrm{~h}$ together with a high temperature $\left(70-80{ }^{\circ} \mathrm{C}\right)$. Sections were washed in Tris buffered saline (TBS), incubated for 5 minutes in 3\% hydrogen peroxide, washed again with TBS and $0.025 \%$ Triton X-100 followed by distilled water, and incubated for 
20 minutes in Protein Block Serum-Free (Dako, USA). A polyclonal rabbit anti-rat primary antibody was used for CD45 detection (anti-CD45 antibody, ab10558, Abcam, United Kingdom) diluted 1:200 and for CD68 detection (anti-CD68 antibody, ab125212, Abcam, United Kingdom) diluted 1:200, incubated overnight in room temperature. Sections were washed in TBS, incubated for $1 \mathrm{~h}$ with a biotylated secondary antibody (Dako, USA) diluted 1:200, and washed again in TBS. Horseradish peroxidase (HRP)-labeled streptavidin (Vector laboratories, USA) was added for $1 \mathrm{~h}$, followed by washing in TBS, and detected by 3,3'-diaminobenzidine (DAB; ACROS Organics, Belgium) substrate for 20 minutes. Finally, sections were washed in TBS and running water (3-4 minutes), counterstained with Mayers HTX (1:5) for 4 minutes, and washed in running water (3-4 minutes).

Estimation of the amount of stained cells for CD45 or CD68 was performed with a light microscope at 4x, 10x, and 20x magnifications. Each specimen was examined by two independent investigators. Both investigators graded the specimens independently from 1-3, where 3 corresponds to a high number of stained cells. The sum of the grades with the different magnifications was calculated, i.e. the grading ranges from 3-9, and then the mean was calculated from the two investigators. There was a discrepancy between the two investigators in 3 specimens (Specimen A and G for CD45 and C for CD68, Figure 3). In these cases a third investigator evaluated the specimens and decided which grade was correct. All investigators were blinded for treatment during the evaluation.

\section{Statistical analysis}


Microarray analysis results were regarded as descriptive. However, possibly regulated genes were defined by use of a p-value $<0.05$ as calculated by Student's t-test and a fold change of $\geq$ 1.5 or $\leq-1.5$. Confirmatory qRT-PCR results and histology were analyzed with Mann-Whitney U test. 


\section{Results}

\section{Day 3}

EGR1 and C-FOS were immediately up-regulated

15 minutes after loading, 11 genes were regulated according to the microarray analysis Day 3

(Table 2). 3 of the genes might be involved in inflammation: Complement component 6 (C6), Ficolin B (FCNB), and Z-DNA binding protein 1 (ZBP1). For confirmation by qRT-PCR, C6 and FCNB were chosen together with 5 genes that have previously been found to be up-regulated by loading at day 5 in healing tendons, namely EGR1, Early growth response 2 (EGR2), FBJ osteosarcoma oncogene (C-FOS), Regulator of G-protein signaling 1 (RGS1), and FBJ osteosarcoma oncogene B (FOSB) (23). All genes could be detected by qRT-PCR, but only 2 genes were significantly up-regulated by mechanical loading, namely EGR1 and C-FOS (Figure 2, Table 3).

Many of the later genes were related to inflammation 3 hours after loading, 136 genes were regulated according to the microarray analysis Day 3 (Table 4). 41 of these genes might be involved in inflammation. 19 of the inflammation-related genes were chosen for confirmation by qRT-PCR. All genes could be detected and 7 genes were significantly up-regulated by loading, namely Chemokine (C-C motif) ligand 20 (CCL20), Chemokine (C-C motif) ligand 7 (CCL7), Interleukin-6 (IL6), Nuclear factor interleukin 3 regulated (NFIL3), Pentraxin related gene (PTX3), Supressor of cytokine signaling 1 (SOCS1), and Toll-like receptor 2 (TLR2) (Figure 3, Table 3). 


\section{Many functions were related to inflammation}

All genes regulated 3 hours after loading, according to the microarray analysis, were analyzed by Ingenuity Pathway analysis software. Overall, most of the functions affected by loading Day 3 could be connected to inflammation. Cellular movement was affected (Table 5) and most of its specific functions were connected to leukocytes, for example chemotaxis of leukocytes and leukocyte migration (Table 6). Other functions that could be connected to inflammation Day 3 were cellular growth and proliferation (generation and stimulation of lymphocytes/leukocytes), cellular development (differentiation of leukocytes) and cell-to-cell signaling and interaction (activation and binding of leukocytes). Also the predicted upstream regulators were inflammation-related Day 3, such as IL-1 $\beta$ (IL1B), IFN- $\gamma$ (IFNG), and TNF (Table 7).

\section{Loading increased the number of leukocytes}

Histological evaluation Day 3 showed mainly immature fibrous tissue interspersed by adipocytes and leukocytes (Figure 4). A majority of the cells in the healing tendon tissue were stained for leukocytes (CD45) and slightly fewer for macrophages (CD68). There was a significant increase of leukocytes in tendons exposed to loading compared to unloaded tendons (p 0.03). However, this difference could not be seen with macrophages (p 0.69). Overall, the leukocytes and macrophages were evenly distributed around and between the tendon stumps, but with a tendency to a higher density around the proximal stump. The leukocytes and macrophages were fewer in the adipose tissue, and also in areas with more mature fibrous tissue. 


\section{Day 14}

IER3 might be up-regulated immediately after mechanical loading 15 minutes after loading, 53 genes were regulated Day 14 according to the microarray analysis (Table 8). EGR1, C-FOS, EGR2 and RGS1 were among those genes. 27 of the 53 genes might be involved in inflammation. For confirmation by qRT-PCR, 13 of the inflammation-related genes were chosen. 11 other regulated genes involved in cell signaling or gene transcription were also chosen for confirmation. All genes, except 2 (IL10 and ELMOD1), could be detected (Figure 5). However, none of the 24 genes analyzed was significantly regulated by loading, although Immediate early response 3 (IER3) was close to statistical significance (p 0.052).

\section{Inflammation seemed not to be affected}

3 hours after loading, 91 genes were regulated according to the microarray analysis Day 14 (Table 9). 26 of these genes might be involved in inflammation. 9 of the inflammation-related genes were chosen for confirmation by qRT-PCR. All genes could be detected but none of them was significantly regulated by loading (Figure 6).

All genes regulated 3 hours after loading, according to the microarray analysis, were analyzed by Ingenuity Pathway analysis software. Overall, loading affected the functions of cellular growth and proliferation, cellular development, and cell-to-cell signaling and interaction Day 14, as it did Day 3 (Table 5). However, there were no specific functions Day 14, so these functions could not be connected to inflammation or leukocytes, as it could Day 3. Although, IL-1 $\beta$ was still predicted to be an activated upstream regulator Day 14 (Table 7). 
Eighteen genes were regulated by mechanical loading both days

3 hours after loading, 18 genes were regulated both Day 3 and Day 14 in a similar way according to the microarray analysis (Table 10). 16 were up-regulated and 2 were down-regulated by loading. 


\section{Discussion}

EGR1 and C-FOS seem important in the immediate response after mechanical loading

The primary gene response after loading involved up-regulation of the transcription factors

EGR1 and C-FOS Day 3. These 2 genes have previously been shown to be up-regulated by loading at day 5 in a similar study, together with EGR2, RGS1 and FOS-B (23). Interestingly, EGR1, C-FOS, EGR2 and RGS1 were also up-regulated Day 14 according to the microarray analysis, but this was not confirmed by qRT-PCR. Still, it is unlikely that these genes would be positive by microarray at two or three different time points by random, since at each time points there were only a few positive genes out of the approximately 25000 genes analyzed. Therefore, it is likely that these genes, especially EGR1 and C-FOS, are the first genes to respond to loading during tendon healing, regardless of healing phase.

EGR1 and C-FOS are early genes, which can be up-regulated by different types of environmental stimuli including mechanical stimulation and tissue injury $(5,11,17,26,48)$. EGR1 can also be induced by growth factors such as transforming growth factor- $\beta$ (TGF- $\beta$ ) (58).

EGR1 is up-regulated during tendon development and seems to be important for tendon cell differentiation, collagen type I production, and can induce expression of the tendon marker scleraxis $(28,34,55)$. EGR1 is also required for optimal wound healing and strongly connected to fibrosis in different tissues as an important mediator of TGF- $\beta$ induced responses $(5,58)$. However, expression of EGR1 in healing tendons has not been associated with fibrosis or scar formation, instead EGR1 has been shown to promote tendon repair (16, 26, 28, 47). 
Additionally, EGR1 has been shown to increase during tendon healing in other studies (16, 23, 28, 47), which suggests that EGR1 is an important gene during tendon healing.

EGR1 might also play a role in inflammation, as EGR-1 null mice have an attenuated inflammatory response and leukocyte activation (58), and EGR1 is also involved in macrophage differentiation (10). Interestingly, EGR1 has been shown to regulate the expression of inflammatory mediators such as IL-6, CCL7, IL-1 $\beta$, and TNF $(12,27,49)$. This suggests that there might be a link between the up-regulated EGR1 at 15 minutes and the up-regulation of IL-6 and CCL7 3 hours later Day 3. It is also possible that IL-1 $\beta$ and TNF, which were predicted upstream regulators 3 hours after loading Day 3, have been activated by EGR1.

FOS proteins like C-FOS, together with Jun proteins, form a complex called activator protein-1 (AP-1). AP-1 is a key transcription factor in osteoblastic differentiation (29). Possibly, AP-1 might also be involved in tenocyte differentiation. Interestingly, the AP-1 complex has a binding site in the promotor for collagen type I, which is the predominating collagen in normal tendons (35).

In summary, EGR1 and C-FOS might be some kind of master regulators of the gene response after mechanical loading during tendon healing. They might improve tendon healing by promoting tendon cell proliferation and differentiation, stimulate collagen type I production, and regulate the inflammatory response. 
Recruitment of leukocytes is increased by mechanical loading Day 3

3 genes involved in recruitment of leukocytes were significantly up-regulated 3 hours after loading Day 3, namely CCL7, CCL20, and PTX3. CCL7 can attract almost all types of leukocytes (50, 56), CCL20 mainly attracts lymphocytes and dendritic cells (14, 61), and PTX3 can dampen leukocyte recruitment by binding of Selectin-P (SELP) (42). These 3 genes can all be produced by fibroblasts and different leukocytes in response to inflammatory mediators such as IL-1 $\beta$ and TNF $(42,44,50,61)$. CCL20 can also be activated by AP-1, the protein complex containing C-FOS and C-JUN. Selectin-E (SELE) and SELP were also up-regulated by loading according to the microarray analysis. They function as cell adhesion molecules on the surfaces of activated endothelial cells and play an important part in recruiting leukocytes to the site of injury (59).

According to Ingenuity pathway analysis, the late gene response Day 3 can largely be connected to an increased recruitment of leukocytes. For example attraction, cell movement, chemotaxis, migration, and mobilization of leukocytes were all activated functions. To confirm these results a histological evaluation was performed Day 3 which showed that there were more leukocytes $\left(\mathrm{CD}_{4} 5^{+}\right.$cells) in the tendons 3 hours after loading compared to unloaded controls. Overall, our results suggest that the recruitment of leukocytes is increased by loading Day 3. However, this could not be shown in a similar study using flow cytometry (6). In that study, mechanical loading did not seem to increase the number of leukocytes in the healing tendons at day 3. Instead, it seemed to prolong M1 type of inflammation by delaying the switch to M2 type of inflammation. However, in the flow cytometry study, the rats were allowed full loading on their 
healing tendons by unrestricted cage activity, which might not be comparable to this study where the healing tendons were only exposed to a single loading episode.

Macrophages and T cells might be affected by mechanical loading Day 3 Many of the genes significantly regulated by loading in the late gene response Day 3 can be expressed in both macrophages (TLR2 (24, 33), NFIL3 (40), SOCS1 (38), IL-6 (38), and SBNO2 (18)) and T cells (TLR2 (33), NFIL3 (40), SOCS1 (54), and IL6 (51)). TLR2 plays a critical role in the detection of pathogen-or damage-associated molecular patterns (PAMPs and DAMPs) to initiate host defense and regulate the inflammatory response (24). SBNO2 is a transcriptional corepressor, which seems to repress inflammatory gene expression (18). SOCS1 suppresses cytokine signaling, is a key regulator of inflammation, and might be involved in macrophage and T cell differentiation $(38,54)$. NFIL3 is a transcription factor that is involved in macrophage activation and $\mathrm{T}$ cell differentiation (40).

Histology showed that the leukocytes in the healing tendon Day 3 were predominantly macrophages. Others have shown that the most prominent immune cell type, 3 days after flexor tendon injury, was from the monocyte/macrophage linage (41). Additionally, there are strikingly more macrophages than $\mathrm{T}$ cells in the healing Achilles tendons at day 3 according to flow cytometry data (6). Interestingly, M1 macrophages are efficient producers of IL-1 $\beta$, TNF and IL6 and associated with TLR, NFkB, and IFN- $\gamma$ (38), which were all up-regulated or predicted upstream regulators in the response to loading Day 3. This suggests that the inflammation-related genes regulated by loading Day 3 might be expressed in macrophages, probably M1 macrophages. 
IL-6 might regulate inflammation and tendon healing Day 3

IL-6 had the highest fold change (FC 6.9) among all genes affected by mechanical loading Day

3. It is a pro-inflammatory cytokine and is expressed by macrophages, $\mathrm{T}$ cells and fibroblasts

$(38,51)$. Apart from its important role during immune responses $(51)$, it is also important for

tendon structure, function, and healing. A deficiency of IL-6 leads to thinner tendons with higher elastic modulus (37) whereas injections of IL-6 into intact human tendons stimulates collagen synthesis (1). Furthermore, IL-6 can be up-regulated by mechanical loading in intact human tendons $(1,32)$.This suggests that IL-6 is important for tendon structure and function and can be induced by mechanical loading. Additionally, IL-6 might also be needed for a normal healing process, as deficiency of IL-6 impairs tendon healing (36). Accordingly, IL-6 is expressed during the first week after Achilles tendon transection in rats (21). In summary, IL-6 might both regulate the inflammatory response and improve tendon healing, possibly by increasing collagen synthesis.

Inflammation seems mainly un-affected by mechanical loading Day 14

There were no inflammation-related genes confirmed by qRT-PCR 3 hours after loading Day 14. This corresponds to the results from the Ingenuity pathway analysis, showing no specific functions connected to inflammation. However, IL-1 $\beta$ was predicted as an upstream regulator which suggests that there might still be some regulation of inflammation. It is possible that some of the 11 inflammation-related genes that were not chosen for confirmation by qRT-PCR, were significantly regulated. 
Genes regulated both days might affect inflammation, extracellular matrix, and fibroblasts 18 genes were regulated both Day 3 and Day 14, 3 hours after loading, in a similar way according to the microarray analysis. These genes might be important for the response to loading in tendon healing, regardless of the healing phase.

Many of these 18 genes could once again be connected to inflammation but also tissue injury and healing, extracellular matrix remodeling, migration, and proliferation (Table 10). TNFRSF12A was up-regulated by loading both days. It is a cell surface receptor and thought to be a major physiologic mediator of tissue repair after acute injury by regulating inflammation, tissue remodeling, migration, differentiation, apoptosis and angiogenesis (4, 9). Interestingly, TNFRSF12A specifically promotes proliferation and increases collagen production in fibroblasts (9). ADAM metallopeptidase 4 (ADAMTS4) was also up-regulated by loading on both days. It is an extracellular matrix protease, expressed in tendons, which can cleave different proteoglycans (15). Expression of ADAMTS4 can be induced by IL-1 $\beta$ and TGF- $\beta(15,57)$. Interestingly, ADAMTS4 might be important during tendon healing as it is increased in ruptured tendons compared to intact tendons in humans (30). In accordance to our results, ADAMTS4 has also been shown to be up-regulated by loading in 5 day healing tendons (21). Hyaluronan synthase 1 (HAS1) , glutamine-fructose-6-phosphate aminotransferase 2 (GFPT2) and UDP-Nacetylhexosamine pyrophosphorylase (UAP1) are strongly connected to each other and were all up-regulated by loading both days. HAS1 is an enzyme responsible for one type of cellular hyaluronan synthesis. GFPT2 and UAP1 are, according to UniProt, enzymes that produce uridine diphosphate N-acetylglucosamine (UDP-GlcNAc), a substrate that is important for HAS1 activity (53). HAS1 can be induced by IL- $1 \beta$, TNF and TGF- $\beta$ and may play a role during 
inflammation as the hyaluronan coat produced by HAS1 mediates a leukocyte recruiting matrix and stimulate transcription of genes related to inflammation (53). Additionally, fibroblasts can express HAS1, and matrix produced by HAS1 is typical for cells of mesenchymal origin such as fibroblasts $(45,53)$. Syndecan-4 (SDC4) was also up-regulated by loading both days. It is a cell surface receptor which is a central mediator of cell adhesion, migration, proliferation and mechanotransduction (19). Interestingly, SDC4 has been shown to promote fibroblast migration during wound healing (8).

In summary, both during the inflammatory and the early remodeling phase of healing, mechanical loading might affect extracellular matrix remodeling, promote migration and proliferation of fibroblasts, increase collagen production, regulate the immune response, and increase leukocyte recruitment.

\section{Limitations}

We have only investigated gene expression and have not studied how this correlates with protein levels. It is unclear how changes in gene expression influence protein production, protein secretion, and cell signaling. The gene expression was studied in the whole healing tissue, which is a mixture of different cell types, so we can only speculate which cells are expressing the genes regulated by loading. Several of the regulated genes have multiple functions depending on in which cell type they are expressed, and it is therefore difficult to draw solid conclusions about their role in this context. Finally, we have not studied the gene response in normal weight bearing tendons without tendon transection which could have controlled for the effects of mechanical loading in normal rats. 


\section{Conclusion}

The immediate gene response after mechanical loading in healing tendons seems to be similar, regardless of the healing phase. The transcription factors EGR1 and C-FOS might be some kind of master regulators of the gene response after mechanical loading during tendon healing. They might regulate the inflammatory response and promote tendon cell proliferation, differentiation and collagen production.

During the inflammatory phase of healing, the late gene response after mechanical loading is strongly connected to inflammation, which is not seen in the early remodeling phase. Mechanical loading seems to increase the recruitment of leukocytes and regulate the inflammatory response by affecting macrophages and T cells during the inflammatory phase of tendon healing. Finally, IL-6 is highly affected by mechanical loading and might be important for both regulating the inflammatory response and improving tendon healing.

This study shows that mechanical loading strongly influences the tissue in healing tendons. As little as a few minutes of mechanical stimulation can change the expression of hundreds of genes and also change the immune cell population. This suggests that even small amounts of mechanical loading might be important during rehabilitation of patients with tendon injuries. 


\section{Acknowledgements}

We would like to thank Sandra Ramstedt for PCR assistance. We would also like to thank the core facility at Novum, BEA, Bioinformatics and Expression Analysis, which is supported by the board of research at the Karolinska Institute and the research committee at the Karolinska hospital.

\section{Grants}

Grants were received from the Swedish Research Council (K2013-52X-02031-47-5) and the Swedish National Centre for Research in Sports.

\section{Disclosure}

The authors report no conflicts of interest. 


\section{References}

1. Andersen $\mathbf{M B}$, Pingel J, Kjaer $\mathbf{M}$, and Langberg $\mathbf{H}$. Interleukin-6: a growth factor stimulating collagen synthesis in human tendon. Journal of applied physiology 110: 1549-1554, 2011.

2. Andersson $\mathbf{T}$, Eliasson $\mathbf{P}$, and Aspenberg $\mathbf{P}$. Tissue memory in healing tendons: short loading episodes stimulate healing. Journal of applied physiology 107: 417-421, 2009.

3. Andersson T, Eliasson P, Hammerman M, Sandberg $\mathbf{O}$, and Aspenberg $\mathbf{P}$. Low-level mechanical stimulation is sufficient to improve tendon healing in rats. Journal of applied physiology 113: 1398-1402, 2012.

4. Bhattacharjee M, Raju R, Radhakrishnan A, Nanjappa V, Muthusamy B, Singh K, Kuppusamy D, Lingala BT, Pan A, Mathur PP, Harsha HC, Prasad TS, Atkins GJ, Pandey A, and Chatterjee A. A Bioinformatics Resource for TWEAK-Fn14 Signaling Pathway. J Signal Transduct 2012: 376470, 2012. 5. Bhattacharyya S, Wu M, Fang F, Tourtellotte W, Feghali-Bostwick C, and Varga J. Early growth response transcription factors: key mediators of fibrosis and novel targets for anti-fibrotic therapy. Matrix biology : journal of the International Society for Matrix Biology 30: 235-242, 2011.

6. Blomgran P, Blomgran R, Ernerudh J, and Aspenberg P. A possible link between loading, inflammation and healing: Immune cell populations during tendon healing in the rat. Scientific reports 6 : 29824, 2016.

7. Bring D, Reno C, Renstrom P, Salo P, Hart D, and Ackermann P. Prolonged immobilization compromises up-regulation of repair genes after tendon rupture in a rat model. Scandinavian journal of medicine \& science in sports 20: 411-417, 2010.

8. Brooks $\mathbf{R}$, Williamson $\mathbf{R}$, and Bass $\mathbf{M}$. Syndecan-4 independently regulates multiple small GTPases to promote fibroblast migration during wound healing. Small GTPases 3: 73-79, 2012.

9. Burkly LC. TWEAK/Fn14 axis: the current paradigm of tissue injury-inducible function in the midst of complexities. Semin Immunol 26: 229-236, 2014.

10. Carter JH, and Tourtellotte WG. Early growth response transcriptional regulators are dispensable for macrophage differentiation. Journal of immunology 178: 3038-3047, 2007.

11. Chiquet $\mathbf{M}$, Renedo AS, Huber F, and Fluck $\mathbf{M}$. How do fibroblasts translate mechanical signals into changes in extracellular matrix production? Matrix biology : journal of the International Society for Matrix Biology 22: 73-80, 2003.

12. Cho SJ, Kang MJ, Homer RJ, Kang HR, Zhang X, Lee PJ, Elias JA, and Lee CG. Role of early growth response-1 (Egr-1) in interleukin-13-induced inflammation and remodeling. The Journal of biological chemistry 281: 8161-8168, 2006.

13. Choi WJ, Park MS, Park KH, Courneya JP, Cho JS, Schon LC, and Lee JW. Comparative analysis of gene expression in normal and degenerative human tendon cells: effects of cyclic strain. Foot Ankle Int 35: 1045-1056, 2014.

14. Comerford I, Bunting M, Fenix K, Haylock-Jacobs S, Litchfield W, Harata-Lee Y, Turvey M, Brazzatti J, Gregor C, Nguyen P, Kara E, and McColl SR. An immune paradox: how can the same chemokine axis regulate both immune tolerance and activation?: CCR6/CCL20: a chemokine axis balancing immunological tolerance and inflammation in autoimmune disease. BioEssays : news and reviews in molecular, cellular and developmental biology 32: 1067-1076, 2010.

15. Corps AN, Jones GC, Harrall RL, Curry VA, Hazleman BL, and Riley GP. The regulation of aggrecanase ADAMTS-4 expression in human Achilles tendon and tendon-derived cells. Matrix biology : journal of the International Society for Matrix Biology 27: 393-401, 2008.

16. Derby BM, Reichensperger J, Chambers C, Bueno RA, Suchy H, and Neumeister MW. Early growth response factor-1: expression in a rabbit flexor tendon scar model. Plast Reconstr Surg 129: 435e-442e, 2012. 
17. Dieckgraefe BK, and Weems DM. Epithelial injury induces egr-1 and fos expression by a pathway involving protein kinase C and ERK. The American journal of physiology 276: G322-330, 1999.

18. El Kasmi KC, Smith AM, Williams L, Neale G, Panopoulos AD, Watowich SS, Hacker H, Foxwell BM, and Murray PJ. Cutting edge: A transcriptional repressor and corepressor induced by the STAT3regulated anti-inflammatory signaling pathway. Journal of immunology 179: 7215-7219, 2007.

19. Elfenbein A, and Simons M. Syndecan-4 signaling at a glance. Journal of cell science 126: 37993804, 2013.

20. Eliasson P, Andersson T, and Aspenberg P. Achilles tendon healing in rats is improved by intermittent mechanical loading during the inflammatory phase. Journal of orthopaedic research : official publication of the Orthopaedic Research Society 30: 274-279, 2012.

21. Eliasson $\mathbf{P}$, Andersson $\mathbf{T}$, and Aspenberg $\mathbf{P}$. Influence of a single loading episode on gene expression in healing rat Achilles tendons. Journal of applied physiology 112: 279-288, 2012.

22. Eliasson $\mathbf{P}$, Andersson $\mathbf{T}$, and Aspenberg P. Rat Achilles tendon healing: mechanical loading and gene expression. Journal of applied physiology 107: 399-407, 2009.

23. Eliasson $\mathbf{P}$, Andersson $\mathbf{T}$, Hammerman $\mathbf{M}$, and Aspenberg $\mathbf{P}$. Primary gene response to mechanical loading in healing rat Achilles tendons. Journal of applied physiology 114: 1519-1526, 2013.

24. Frey H, Schroeder N, Manon-Jensen T, lozzo RV, and Schaefer L. Biological interplay between proteoglycans and their innate immune receptors in inflammation. The FEBS journal 280: 2165-2179, 2013.

25. Galloway MT, Lalley AL, and Shearn JT. The role of mechanical loading in tendon development, maintenance, injury, and repair. The Journal of bone and joint surgery American volume 95: 1620-1628, 2013.

26. Gaut L, Robert N, Delalande A, Bonnin MA, Pichon C, and Duprez D. EGR1 Regulates Transcription Downstream of Mechanical Signals during Tendon Formation and Healing. PloS one 11: e0166237, 2016.

27. Giri RK, Selvaraj SK, and Kalra VK. Amyloid peptide-induced cytokine and chemokine expression in THP-1 monocytes is blocked by small inhibitory RNA duplexes for early growth response-1 messenger RNA. Journal of immunology 170: 5281-5294, 2003.

28. Guerquin MJ, Charvet B, Nourissat G, Havis E, Ronsin O, Bonnin MA, Ruggiu M, OliveraMartinez I, Robert N, Lu Y, Kadler KE, Baumberger T, Doursounian L, Berenbaum F, and Duprez D. Transcription factor EGR1 directs tendon differentiation and promotes tendon repair. The Journal of clinical investigation 123: 3564-3576, 2013.

29. Jensen ED, Gopalakrishnan R, and Westendorf JJ. Regulation of gene expression in osteoblasts. Biofactors 36: 25-32, 2010.

30. Jones GC, Corps AN, Pennington CJ, Clark IM, Edwards DR, Bradley MM, Hazleman BL, and Riley GP. Expression profiling of metalloproteinases and tissue inhibitors of metalloproteinases in normal and degenerate human achilles tendon. Arthritis and rheumatism 54: 832-842, 2006.

31. Killian ML, Cavinatto L, Galatz LM, and Thomopoulos S. The role of mechanobiology in tendon healing. Journal of shoulder and elbow surgery / American Shoulder and Elbow Surgeons [et al] 21: 228237, 2012.

32. Langberg H, Olesen JL, Gemmer C, and Kjaer M. Substantial elevation of interleukin-6 concentration in peritendinous tissue, in contrast to muscle, following prolonged exercise in humans. The Journal of physiology 542: 985-990, 2002.

33. Leifer CA, and Medvedev AE. Molecular mechanisms of regulation of Toll-like receptor signaling. Journal of leukocyte biology 100: 927-941, 2016.

34. Lejard V, Blais F, Guerquin MJ, Bonnet A, Bonnin MA, Havis E, Malbouyres M, Bidaud CB, Maro G, Gilardi-Hebenstreit P, Rossert J, Ruggiero F, and Duprez D. EGR1 and EGR2 involvement in vertebrate tendon differentiation. The Journal of biological chemistry 286: 5855-5867, 2011. 
35. Lin $\mathrm{CH}$, Yu MC, Tung WH, Chen TT, Yu CC, Weng CM, Tsai YJ, Bai KJ, Hong CY, Chien MH, and Chen BC. Connective tissue growth factor induces collagen I expression in human lung fibroblasts through the Rac1/MLK3/JNK/AP-1 pathway. Biochimica et biophysica acta 1833: 2823-2833, 2013.

36. Lin TW, Cardenas L, Glaser DL, and Soslowsky $\mathrm{L}$. Tendon healing in interleukin-4 and interleukin-6 knockout mice. Journal of biomechanics 39: 61-69, 2006.

37. Lin TW, Cardenas L, and Soslowsky $\amalg$. Tendon properties in interleukin-4 and interleukin- 6 knockout mice. Journal of biomechanics 38: 99-105, 2005.

38. Locati M, Mantovani A, and Sica A. Macrophage activation and polarization as an adaptive component of innate immunity. Advances in immunology 120: 163-184, 2013.

39. Maeda T, Sakabe T, Sunaga A, Sakai K, Rivera AL, Keene DR, Sasaki T, Stavnezer E, lannotti J, Schweitzer R, Ilic D, Baskaran H, and Sakai T. Conversion of mechanical force into TGF-beta-mediated biochemical signals. Current biology : CB 21: 933-941, 2011.

40. Male V, Nisoli I, Gascoyne DM, and Brady HJ. E4BP4: an unexpected player in the immune response. Trends in immunology 33: 98-102, 2012.

41. Manning CN, Havlioglu N, Knutsen E, Sakiyama-Elbert SE, Silva MJ, Thomopoulos S, and Gelberman RH. The early inflammatory response after flexor tendon healing: a gene expression and histological analysis. Journal of orthopaedic research : official publication of the Orthopaedic Research Society 32: 645-652, 2014.

42. Mantovani A, Valentino S, Gentile S, Inforzato A, Bottazzi B, and Garlanda C. The long pentraxin PTX3: a paradigm for humoral pattern recognition molecules. Annals of the New York Academy of Sciences 1285: 1-14, 2013.

43. McAllister KA, Grogg KM, Johnson DW, Gallione CJ, Baldwin MA, Jackson CE, Helmbold EA, Markel DS, McKinnon WC, Murrell J, and et al. Endoglin, a TGF-beta binding protein of endothelial cells, is the gene for hereditary haemorrhagic telangiectasia type 1. Nature genetics 8: 345-351, 1994.

44. Menten P, Proost P, Struyf S, Van Coillie E, Put W, Lenaerts JP, Conings R, Jaspar JM, De Groote D, Billiau A, Opdenakker G, and Van Damme J. Differential induction of monocyte chemotactic protein-3 in mononuclear leukocytes and fibroblasts by interferon-alpha/beta and interferon-gamma reveals MCP-3 heterogeneity. European journal of immunology 29: 678-685, 1999.

45. Meran S, Thomas D, Stephens P, Martin J, Bowen T, Phillips A, and Steadman R. Involvement of hyaluronan in regulation of fibroblast phenotype. The Journal of biological chemistry 282: 2568725697, 2007.

46. Morey-Holton ER, and Globus RK. Hindlimb unloading rodent model: technical aspects. Journal of applied physiology 92: 1367-1377, 2002.

47. Nourissat G, Berenbaum F, and Duprez D. Tendon injury: from biology to tendon repair. Nature reviews Rheumatology 11: 223-233, 2015.

48. Papadopoulou A, lliadi A, Eliades T, and Kletsas D. Early responses of human periodontal ligament fibroblasts to cyclic and static mechanical stretching. European journal of orthodontics 2016.

49. Pawlinski R, Pedersen B, Kehrle B, Aird WC, Frank RD, Guha M, and Mackman N. Regulation of tissue factor and inflammatory mediators by Egr-1 in a mouse endotoxemia model. Blood 101: 39403947, 2003.

50. Proost P, Wuyts A, and Van Damme J. Human monocyte chemotactic proteins-2 and -3: structural and functional comparison with MCP-1. Journal of leukocyte biology 59: 67-74, 1996.

51. Schaper F, and Rose-John S. Interleukin-6: Biology, signaling and strategies of blockade. Cytokine \& growth factor reviews 26: 475-487, 2015.

52. Schepull T, and Aspenberg P. Early controlled tension improves the material properties of healing human achilles tendons after ruptures: a randomized trial. The American journal of sports medicine 41: 2550-2557, 2013. 
53. Siiskonen H, Oikari S, Pasonen-Seppanen S, and Rilla K. Hyaluronan synthase 1: a mysterious enzyme with unexpected functions. Frontiers in immunology 6: 43, 2015.

54. Tamiya T, Kashiwagi I, Takahashi R, Yasukawa H, and Yoshimura A. Suppressors of cytokine signaling (SOCS) proteins and JAK/STAT pathways: regulation of T-cell inflammation by SOCS1 and SOCS3. Arteriosclerosis, thrombosis, and vascular biology 31: 980-985, 2011.

55. Tao X, Liu J, Chen L, Zhou Y, and Tang K. EGR1 induces tenogenic differentiation of tendon stem cells and promotes rabbit rotator cuff repair. Cell Physiol Biochem 35: 699-709, 2015.

56. Tsou CL, Peters W, Si Y, Slaymaker S, Aslanian AM, Weisberg SP, Mack M, and Charo IF. Critical roles for CCR2 and MCP-3 in monocyte mobilization from bone marrow and recruitment to inflammatory sites. The Journal of clinical investigation 117: 902-909, 2007.

57. Tsuzaki M, Guyton G, Garrett W, Archambault JM, Herzog W, Almekinders L, Bynum D, Yang X, and Banes AJ. IL-1 beta induces COX2, MMP-1, -3 and -13, ADAMTS-4, IL-1 beta and IL- 6 in human tendon cells. Journal of orthopaedic research : official publication of the Orthopaedic Research Society 21: 256-264, 2003.

58. Wu M, Melichian DS, de la Garza M, Gruner K, Bhattacharyya S, Barr L, Nair A, Shahrara S, Sporn PH, Mustoe TA, Tourtellotte WG, and Varga J. Essential roles for early growth response transcription factor Egr-1 in tissue fibrosis and wound healing. The American journal of pathology 175: 1041-1055, 2009.

59. Zarbock A, Ley K, McEver RP, and Hidalgo A. Leukocyte ligands for endothelial selectins: specialized glycoconjugates that mediate rolling and signaling under flow. Blood 118: 6743-6751, 2011. 60. Zhang J, Yuan T, and Wang JH. Moderate treadmill running exercise prior to tendon injury enhances wound healing in aging rats. Oncotarget 7: 8498-8512, 2016.

61. Zhao L, Xia J, Wang X, and Xu F. Transcriptional regulation of CCL20 expression. Microbes Infect 16: 864-870, 2014. 


\section{Figure legends}

Figure 1. Experimental design. All rats had their right Achilles tendon transected and were tail suspended continuously from Day 1 . At the day of euthanasia (Day 3 or Day 14) the rats were either euthanized directly to serve as controls (A) or were exposed to loading by walking on a treadmill for 5 minutes. Those exposed to loading were either euthanized 15 minutes after walking had started (B) or tail suspended again and euthanized 3 hours later (C).

Figure 2. Genes regulated 15 minutes after mechanical loading in healing tendons Day 3. C6 and FCNB were significantly regulated by loading according to the microarray analysis (Student's t-test; N=4). C-FOS and EGR1 were significantly up-regulated by loading according to qRT-PCR (Mann Whitney U-test; N=7 loading, 6 unloading). FOSB was not detected by microarray. $\cdot=$ fold change $>1.5$ or $<-1.5$ together with $\mathrm{p}<0.05 . \cdot=$ fold change $>1.5$ and $\mathrm{p}=$ 0.07

Figure 3. Genes regulated 3 hours after mechanical loading in healing tendons Day 3. All of these genes were significantly regulated by loading according to the microarray analysis (Student's t-test, N=4). CCL20, CCL7, IL-6, NFIL3, PTX3, SOCS1, and TLR2 were significantly up-regulated by loading according to qRT-PCR (Mann Whitney U-test, N=4 loading, 6 unloading). RHOH, SELE and SOCS3 were not detected by qRT-PCR. • = fold change $>1.5$ or $<-1.5$ together with $\mathrm{p}<0.05 \cdot=$ fold change $>1.5$ and $\mathrm{p}=0.063$

Figure 4. Histology of healing tendons Day 3. A) Unloaded healing tendon (Rat A) stained with Hematoxylin and Eosin. The old tendon stump is seen in the upper part of the picture on the 
right side. B) Loaded healing tendon (Rat $\mathrm{H}$ ) stained for $\mathrm{CD}^{+} 8^{+}$cells (macrophages) and detected by immunoperoxidase staining (brown) in 10x magnification. The picture corresponds to approximately the same area as seen in D. C) Unloaded healing tendon (Rat A) stained for CD45 ${ }^{+}$cells (leukocytes) and detected by immunoperoxidase staining (brown) in 10x magnification. D) Loaded healing tendon (Rat $\mathrm{H}$ ) stained for $\mathrm{CD}^{4} 5^{+}$cells and detected by immunoperoxidase staining in 10x magnification. Picture C and D corresponds to an area with the highest amount of leukocytes in the healing tissue (brown cells). E) Histological evaluation of leukocyte (CD45) and macrophage (CD68) staining. The table shows the mean of two independent investigators. The specimens were graded from 1-3 in 3 different magnifications (4x, 10x and 20x), i.e. grading ranges from 3-9 (where 9 correspond to a high number of stained cells).

Figure 5. Genes regulated 15 minutes after mechanical loading in healing tendons Day 14. All of these genes were significantly regulated by loading according to the microarray analysis (Student's t-test, N=4) except EGR2 and FOSB which were not detected. No genes were significantly regulated according to qRT-PCR (Mann Whitney U-test, N=6 loading, 5 unloading). ELMOD1 and IL-10 were not detected by qRT-PCR. $\cdot=$ fold change $>1.5$ and $\mathrm{p}=$ 0.052

Figure 6. Genes regulated 3 hours after mechanical loading in healing tendons Day 14. All of these genes were significantly regulated by loading according to the microarray analysis (Student's t-test, N=4). No genes were significantly regulated according to qRT-PCR (Mann Whitney U-test, N=5). LILRA5 and ELMOD1 were not detected by qRT-PCR. 
Table 1. Primers used for quantitative real-time PCR.

Table 2. Microarray: Genes regulated 15 minutes after loading Day 3

11 genes were significantly regulated according to the microarray results (Student's t-test, $\mathrm{N}=4$ ). 3 genes might play a role in the inflammatory response according to gene ontology $(*)$. 2 genes were chosen for confirmation with qRT-PCR (bold).

Table 3. Fold change and confidence interval for regulated genes. Foldchange (FC) from qRT-PCR analysis. The result is analyzed with Mann-Whitney $\mathrm{U}$ test $(\mathrm{N}=4-7)$.

\section{Table 4. Microarray: Genes regulated 3 hours after loading Day 3}

136 genes were significantly regulated according to the microarray analysis (Student's t-test, $\mathrm{N}=4)$. 41 genes might play a role in the inflammatory response according to gene ontology $(*)$. 19 genes were chosen for confirmation with qRT-PCR (bold).

Table 5. Top five of molecular and cellular functions in Ingenuity Pathway Analysis. All genes regulated 3 hours after loading Day 3 and Day 14 (according to the microarray analysis, fold change $\geq 1.5$ or $\leq-1.5$ together with a p-value of $<0.05$, Student's t-test, $N=4$ ) were analyzed by Ingenuity Pathway analysis software. "Molecules involved” means how many significantly regulated genes in the microarray analysis were involved in that specific molecular and cellular function. All specific functions had an activation z-score $>2$, as a definition for activation. 
Table 6. Specific functions from Ingenuity pathway analysis, 3 hours after loading Day 3. All genes regulated 3 hours after loading Day 3 (according to microarray analysis, fold change $\geq$ 1.5 or $\leq-1.5$ together with a p-value of $<0.05$, Student's t-test, $\mathrm{N}=4$ ) were analyzed by Ingenuity Pathway analysis software. All specific functions in the table had a p-value $<0.05$. A means activation z-score. B means number of genes that can be connected to this function and was significantly regulated according to the microarray analysis. C means belongs to the molecular and cellular functions of: 1) cellular movement 2) cellular growth and proliferation 3) cellular development 4) cell death and survival 5) cell-to-cell signaling and interaction.

Table 7. Top five of upstream regulators in Ingenuity Pathway Analysis. All genes regulated 3 hours after loading Day 3 and Day 14 (according to the microarray analysis, fold change $\geq 1.5$ or $\leq-1.5$ together with a p-value of $<0.05$, Student's t-test, $N=4$ ) were analyzed by Ingenuity Pathway analysis software.

Table 8. Microarray: Genes regulated 15 minutes after loading Day 14

53 genes were significantly regulated according to the microarray analysis (Student's t-test, $\mathrm{N}=4$ ). 27 genes might play a role in the inflammatory response according to gene ontology $\left(^{*}\right)$.

22 genes were chosen for confirmation with qRT-PCR (bold), some of them might play a role in the inflammatory response $\left(^{*}\right)$ and some might be involved in cell signaling and gene transcription.

Table 9. Microarray: Genes regulated 3 hours after loading Day 14 
91 genes were significantly regulated according to the microarray analysis (Student's t-test, $\mathrm{N}=4) .26$ genes might play a role in the inflammatory response according to gene ontology $(*) .9$ genes were chosen for confirmation with qRT-PCR (bold).

Table 10. Genes regulated 3 hours after loading Day 3 and Day 14. Genes regulated on both days according to the microarray analysis (Student's t-test, $\mathrm{N}=4$ ). FC means fold change. $\mathrm{p}$ means p-value. Biological process: I means inflammation, TI\&H means tissue injury and healing, EM means extracellular matrix, M means migration, and P means proliferation. 


\begin{tabular}{|c|c|c|c|}
\hline \multicolumn{2}{|c|}{ Gene symbol Gene name } & \multirow{2}{*}{$\begin{array}{l}\text { Assay identification } \\
\text { Rn00563784 m1 }\end{array}$} & \multirow{2}{*}{$\begin{array}{l}\text { Accession } \\
\text { NM_012912.2 }\end{array}$} \\
\hline Atf3 & Activating transcription factor 3 & & \\
\hline C3 & Complement component 3 & Rn00566466_m1 & NM_016994.2 \\
\hline C6 & Complement component 6 & Rn00598544_m1 & NM_176074.3 \\
\hline Cl120 & Chemokine (C-C motif) ligand 20 & Rn00570287_m1 & NM_019233.1 \\
\hline $\mathrm{Ccl} 3$ & Chemokine (C-C motif) ligand 3 & Rn01464736_g1 & NM_013025.2 \\
\hline $\mathrm{Ccl} 6$ & Chemokine (C-C motif) ligand 6 & Rn01456400_m1 & NM_001004202.2 \\
\hline $\mathrm{CCl} 7$ & Chemokine (C-C motif) ligand 7 & Rn01467286_m1 & NM_001007612.1 \\
\hline Ccr5 & Chemokine (C-C motif) receptor 5 & Rn02132969_s1 & NM_053960.3 \\
\hline Cd 80 & Cd80 molecule & Rn00709368_m1 & NM_012926.1 \\
\hline Cxcl10 & Chemokine (C-X-C motif) ligand 10 & Rn01413889_g1 & NM_139089.1 \\
\hline Cxcl13 & Chemokine (C-X-C motif) ligand 13 & Rn01450028_m1 & NM_001017496.1 \\
\hline Egr1 & Early growth response 1 & Rn00561138_m1 & NM_012551.2 \\
\hline Egr2 & Early growth response 2 & Rn00586224_m1 & NM_053633.1 \\
\hline Egr3 & Early growth response 3 & Rn00567228_m1 & NM_017086.1 \\
\hline Elmod1 & ELMO/CED-12 domain containing 1 & Rn01421567_m1 & NM_001191579.1 \\
\hline Fcnb & Ficolin B & Rn00586231_m1 & NM_053634.1 \\
\hline Fos & FBJ osteosarcoma oncogene (c-Fos) & Rn00487426_g1 & NM_022197.2 \\
\hline Fosb & FBJ osteosarcoma oncogene B & Rn00500401_m1 & NM_001256509.1 \\
\hline ler2 & Immediate early response 2 & Rn02531674_s1 & NM_001009541.1 \\
\hline ler3 & Immediate early response 3 & Rn03993554_g1 & NM_212505.2 \\
\hline$\| 10$ & Interleukin 10 & Rn00563409_m1 & NM_012854.2 \\
\hline$\| 1 \mathrm{~b}$ & Interleukin 1 beta & Rn00580432_m1 & NM_031512.2 \\
\hline$\| 1|r| 1$ & Interleukin 1 receptor-like 1 & Rn01640664_m1 & NM_001127689.1 \\
\hline$\| 4$ ra & Interleukin 4 receptor & Rn01507024_m1 & NM_133380.2 \\
\hline 116 & Interleukin 6 & Rn01410330_m1 & NM_012589.2 \\
\hline Itga2 & Integrin, alpha 2 & Rn01489315_m1 & XM_345156.7 \\
\hline Junb & Jun B proto-oncogene & Rn00572994_s1 & NM_021836.2 \\
\hline & Leukocyte immunoglobulin-like receptor, & & \\
\hline Lilra5 & subfamily A (with TM domain), member 5 & Rn04222694_mH & NM_001076793.1 \\
\hline Msr1 & Macrophage scavenger receptor 1 & Rn01488115_m1 & NM_001191939.1 \\
\hline Nfil3 & Nuclear factor, interleukin 3 regulated & Rn01434874_s1 & NM_053727.2 \\
\hline Nfkbiz & $\begin{array}{l}\text { Nuclear factor of kappa light polypeptide gene } \\
\text { enhancer in B-cells inhibitor zeta. }\end{array}$ & Rn01474603 m1 & NM 001107095.1 \\
\hline Ptges & Prostaglandin E synthase & Rn00572047_m1 & NM_021583.3 \\
\hline Ptgs2 & Prostaglandin-endoperoxide synthase 2 (COX-2) & Rn01483828_m1 & NM_017232.3 \\
\hline Ptx3 & Pentraxin 3 , long & Rn01769850_m1 & NM_001109536.1 \\
\hline Rgs1 & Regulator of G-protein signaling 1 & Rn01483325_m1 & NM_019336.1 \\
\hline Rgs2 & Regulator of G-protein signaling 2 & Rn00584932_m1 & NM_053453.2 \\
\hline Rgs6 & Regulator of G-protein signaling 6 & Rn01517937_m1 & NM_019342.1 \\
\hline Rhoh & Ras homolog family member $\mathrm{H}$ & Rn01417510_m1 & NM_001013430.1 \\
\hline Ripk3 & Receptor-interacting serine-threonine kinase 3 & Rn01481949_g1 & NM_139342.1 \\
\hline Sbno2 & Strawberry notch homolog 2 (Drosophila) & Rn01408530_m1 & NM_001108068.1 \\
\hline Sele & Selectin $\mathrm{E}$ & Rn00594072_m1 & NM_138879.1 \\
\hline Selp & Selectin $\mathrm{P}$ & Rn00565416_m1 & NM_013114.1 \\
\hline Socs1 & Suppressor of cytokine signaling 1 & Rn00595838_s1 & NM_145879.1 \\
\hline Tr2 & Toll-like receptor 2 & Rn02133647_s1 & NM_198769.2 \\
\hline & $\begin{array}{l}\text { Tumor necrosis factor receptor superfamily, } \\
\text { member } 12 a\end{array}$ & Rn00710373 m1 & NM 181086.2 \\
\hline $\begin{array}{l}\text { Tnfrst12a } \\
\text { Xcr1 }\end{array}$ & $\begin{array}{l}\text { member } 12 \mathrm{a} \\
\text { Chemokine (C motif) receptor } 1\end{array}$ & Rn03037149_s1 & NM_001106871.1 \\
\hline
\end{tabular}




\begin{tabular}{|l|l|c|c|}
\hline Gene & Gene name & FC & p \\
\hline C6* & complement component 6 & $\mathbf{1 . 6 4}$ & $\mathbf{0 . 0 1 6}$ \\
Ccdc152 & coiled-coil domain containing 152 & 1.50 & 0.027 \\
Fcnb* & ficolin B & $\mathbf{- 1 . 9 2}$ & $\mathbf{0 . 0 3 4}$ \\
Mir323 & microRNA mir-323 & 1.63 & 0.040 \\
Mir487b & microRNA mir-487b & 1.55 & 0.015 \\
Rnf213 & ring finger protein 213 & 1.54 & 0.039 \\
Rnf213 & ring finger protein 213 & 1.58 & 0.037 \\
Rnf213 & ring finger protein 213 & 1.55 & 0.039 \\
Rnf213 & ring finger protein 213 & 1.57 & 0.049 \\
Slc2a5 & solute carrier family 2 (facilitated glucose/fructose transporter). & 1.55 & 0.013 \\
Zbp1* & member 5 & & \\
\hline
\end{tabular}




\begin{tabular}{llcccc}
\hline & \multicolumn{5}{c}{ Confidence interval limits } \\
& Gene & FC & Lower & Higher & p-value \\
\hline \multirow{2}{*}{ Day 3 15 min } & C-FOS & 4.6 & 2.17 & 11.29 & $<0.05$ \\
& EGR1 & 2.5 & 1.42 & 4.78 & $<0.05$ \\
& RGS1 & 1.9 & 0.97 & 3.71 & 0.07 \\
\hline \multirow{2}{*}{ Day 3 3 h } & CCL20 & 3.6 & 2 & 6.26 & $<0.05$ \\
& CCL7 & 4.2 & 1.08 & 7.3 & $<0.05$ \\
& IL4RA & 3.7 & 0.8 & 7.26 & 0.063 \\
& IL6 & 7.2 & 2.2 & 14.59 & $<0.05$ \\
& NFIL3 & 2.2 & 1.11 & 3.11 & $<0.05$ \\
& PTX3 & 4.1 & 1.18 & 7.73 & $<0.05$ \\
& SBNO2 & 2.5 & 0.92 & 4.57 & 0.063 \\
& SELP & 3.2 & 0.67 & 6.88 & 0.11 \\
& SOCS1 & 2.9 & 1.21 & 4.81 & $<0.05$ \\
& TLR2 & 3 & 1 & 6.42 & $<0.05$ \\
\hline \multirow{2}{*}{ Day 14 15 min } & IER3 & 1.6 & 1 & 2.36 & 0.052 \\
\hline
\end{tabular}




\begin{tabular}{|c|c|c|c|}
\hline Gene & Gene name & FC & $\mathbf{p}$ \\
\hline Adamts1* & ADAM metallopeptidase with thrombospondin type 1 motif. 1 & 1.84 & 0.004 \\
\hline Adamts4* & $\begin{array}{l}\text { ADAM metallopeptidase with thrombospondin type } 1 \text { motif. } 4 \\
\text { a disintegrin-like and metalloprotease (reprolysin type) with }\end{array}$ & 2.37 & 0.001 \\
\hline Adamts9 & thrombospondin type 1 motif. 9 & 1.81 & 0.008 \\
\hline Adora2b & adenosine $\mathrm{A} 2 \mathrm{~B}$ receptor & 2.19 & 0.004 \\
\hline Agtr1a & angiotensin II receptor. type 1a & 1.63 & 0.040 \\
\hline Arntl & aryl hydrocarbon receptor nuclear translocator-like & 1.63 & 0.005 \\
\hline Baz1a & bromodomain adjacent to zinc finger domain. $1 \mathrm{~A}$ & 1.55 & 0.009 \\
\hline $\mathbf{C 3}^{*}$ & complement component 3 & 1.85 & 0.018 \\
\hline Ccl20* & chemokine (C-C motif) ligand 20 & 2.48 & 0.029 \\
\hline Ccl7* & chemokine (C-C motif) ligand 7 & 1.72 & 0.012 \\
\hline Cenf & cyclin F & 1.51 & 0.011 \\
\hline Ccnjl & cyclin J-like & 1.79 & 0.010 \\
\hline Ccr5* & chemokine (C-C motif) receptor 5 & 1.67 & 0.011 \\
\hline Cd80* & Cd80 molecule & 1.69 & 0.034 \\
\hline Cebpb* & CCAAT/enhancer binding protein (C/EBP). beta & 1.60 & 0.029 \\
\hline Chst11 & carbohydrate (chondroitin 4) sulfotransferase 11 & 1.64 & 0.001 \\
\hline Chsy1 & chondroitin sulfate synthase 1 & 1.64 & 0.002 \\
\hline Coq10b & coenzyme Q10 homolog B (S. cerevisiae) & 1.52 & 0.018 \\
\hline Crem & cAMP responsive element modulator & 2.02 & 0.007 \\
\hline Ctgf & connective tissue growth factor & -1.84 & 0.000 \\
\hline Cth & cystathionase (cystathionine gamma-lyase) & 1.59 & 0.005 \\
\hline Cxcl10* & chemokine (C-X-C motif) ligand 10 & 1.69 & 0.015 \\
\hline Dbp & D site of albumin promoter (albumin D-box) binding protein & -1.57 & 0.001 \\
\hline Dusp5 & dual specificity phosphatase 5 & 1.59 & 0.040 \\
\hline E2f5 & E2F transcription factor 5 & 1.64 & 0.001 \\
\hline Epm2a & epilepsy. progressive myoclonus type $2 \mathrm{~A}$ & -1.52 & 0.006 \\
\hline Ereg* & epiregulin & 1.56 & 0.014 \\
\hline Fbxo32 & F-box protein 32 & -1.57 & 0.006 \\
\hline Fcnb* & ficolin B & 3.30 & 0.012 \\
\hline Fgf23 & fibroblast growth factor 23 & 3.03 & 0.001 \\
\hline Fmo5 & flavin containing monooxygenase 5 & 1.89 & 0.002 \\
\hline Fosl1 & fos-like antigen 1 & 2.64 & 0.026 \\
\hline G0s2 & G0/G1switch 2 & -1.51 & 0.007 \\
\hline Gadd45g & growth arrest and DNA-damage-inducible. gamma & 1.55 & 0.004 \\
\hline Gbx2 & gastrulation brain homeobox 2 & 2.05 & 0.000 \\
\hline Gch1 & GTP cyclohydrolase 1 & 1.54 & 0.013 \\
\hline Gfpt $2 *$ & glutamine-fructose-6-phosphate transaminase 2 & 1.82 & 0.003 \\
\hline Gnat1 & guanine nucleotide binding protein. alpha transducing 1 & 1.87 & 0.044 \\
\hline Gpr155 & G protein-coupled receptor 155 & -1.52 & 0.032 \\
\hline Gpr34* & G protein-coupled receptor 34 & -1.53 & 0.017 \\
\hline Gpr39 & G protein-coupled receptor 39 & 1.62 & 0.003 \\
\hline
\end{tabular}




\begin{tabular}{|c|c|c|c|}
\hline Gprc5a & G protein-coupled receptor. family C. group 5 . member A & 1.55 & 0.031 \\
\hline Has $1 *$ & hyaluronan synthase 1 & 3.22 & 0.017 \\
\hline Has $2 *$ & hyaluronan synthase 2 & 2.26 & 0.001 \\
\hline Heatr3* & HEAT repeat containing 3 & 1.58 & 0.006 \\
\hline Hk2 & hexokinase 2 & 1.82 & 0.017 \\
\hline Hs3st3b1 & heparan sulfate (glucosamine) 3-O-sulfotransferase 3B1 & 1.54 & 0.002 \\
\hline Hspb8 & heat shock protein $\mathrm{B} 8$ & 1.52 & 0.018 \\
\hline Hsph1 & heat shock $105 \mathrm{kDa} / 110 \mathrm{kDa}$ protein 1 & 1.67 & 0.007 \\
\hline Il28ra* & interleukin 28 receptor alpha & 1.56 & 0.005 \\
\hline II4ra* & interleukin 4 receptor. alpha & 1.67 & 0.004 \\
\hline $116^{*}$ & interleukin 6 & 3.78 & 0.011 \\
\hline Inhba & inhibin beta-A & 3.84 & 0.021 \\
\hline $\operatorname{Irf7*}$ & interferon regulatory factor 7 & 1.62 & 0.019 \\
\hline Isg $15^{*}$ & $\begin{array}{l}\text { ISG15 ubiquitin-like modifier } \\
\text { potassium voltage-gated channel. subfamily } \mathrm{H} \text { (eag-related). }\end{array}$ & 1.63 & 0.003 \\
\hline Kenh1 & member 1 & 1.56 & 0.023 \\
\hline Klf11 & Kruppel-like factor 11 & -1.64 & 0.010 \\
\hline LOC500300 & similar to hypothetical protein MGC6835 & -1.57 & 0.016 \\
\hline LOC686567 & similar to Epiplakin & -1.54 & 0.017 \\
\hline Ly6c & Ly6-C antigen & 1.59 & 0.048 \\
\hline Mcoln2 & mucolipin 2 & 1.60 & 0.027 \\
\hline Mcoln3 & mucolipin 3 & 1.76 & 0.011 \\
\hline Mfap31 & microfibrillar-associated protein 3-like & 1.99 & 0.005 \\
\hline Mir323 & microRNA mir-323 & 2.12 & 0.012 \\
\hline Mir539 & microRNA mir-539 & 1.54 & 0.019 \\
\hline $\mathrm{Mx} 1 *$ & myxovirus (influenza virus) resistance 1 & 1.98 & 0.044 \\
\hline Myc & myelocytomatosis oncogene & 1.56 & 0.017 \\
\hline Ncapg2 & non-SMC condensin II complex. subunit G2 & 1.57 & 0.001 \\
\hline Nfil3* & nuclear factor. interleukin 3 regulated & 1.64 & 0.003 \\
\hline Nfya & nuclear transcription factor-Y alpha & 1.56 & 0.009 \\
\hline $\mathrm{Ngf}$ & nerve growth factor (beta polypeptide) & 1.50 & 0.001 \\
\hline Npas2 & neuronal PAS domain protein 2 & 1.52 & 0.048 \\
\hline $\operatorname{Nr} 1 \mathrm{~d} 1 *$ & nuclear receptor subfamily 1 . group D. member 1 & -2.82 & 0.000 \\
\hline $\operatorname{Nrg} 1$ & neuregulin 1 & 2.02 & 0.042 \\
\hline Nrk & Nik related kinase & 1.69 & 0.043 \\
\hline Oas1a* & $2 '-5$ ' oligoadenylate synthetase $1 \mathrm{~A}$ & 1.76 & 0.039 \\
\hline Oasl2 & 2'-5' oligoadenylate synthetase-like 2 & 1.84 & 0.016 \\
\hline Orc1l & origin recognition complex. subunit 1-like (yeast) & 1.52 & 0.013 \\
\hline Pappa & pregnancy-associated plasma protein $\mathrm{A}$ & 1.89 & 0.014 \\
\hline Pck1 & phosphoenolpyruvate carboxykinase 1 (soluble) & -1.89 & 0.000 \\
\hline Pdk4 & pyruvate dehydrogenase kinase. isozyme 4 & -1.52 & 0.033 \\
\hline Peg12 & paternally expressed 12 & 1.59 & 0.001 \\
\hline Penk & proenkephalin & 1.74 & 0.012 \\
\hline
\end{tabular}




\begin{tabular}{|c|c|c|c|}
\hline Per1 & period homolog 1 (Drosophila) & -1.64 & 0.042 \\
\hline Per3 & period homolog 3 (Drosophila) & -2.11 & 0.000 \\
\hline Pik3ip1 & phosphoinositide-3-kinase interacting protein 1 & -2.20 & 0.005 \\
\hline Plac8 & placenta-specific 8 & 1.50 & 0.000 \\
\hline Plau & plasminogen activator. urokinase & 1.51 & 0.014 \\
\hline Plaur & plasminogen activator. urokinase receptor & 1.51 & 0.041 \\
\hline Plek & pleckstrin & 1.52 & 0.037 \\
\hline Polr1b & polymerase (RNA) I polypeptide B & 1.62 & 0.014 \\
\hline Pot $1 b$ & protection of telomeres $1 \mathrm{~B}$ & -1.54 & 0.001 \\
\hline Pragmin & pragma of Rnd2 & 2.03 & 0.025 \\
\hline Ptges* & prostaglandin E synthase & 1.56 & 0.027 \\
\hline Ptx3* & pentraxin related gene & 2.66 & 0.004 \\
\hline Rab20 & RAB20. member RAS oncogene family & 1.51 & 0.029 \\
\hline RGD1560289 & similar to chromosome 3 open reading frame 20 & -1.57 & 0.005 \\
\hline RGD1562846 & $\begin{array}{l}\text { similar to Docking protein } 5 \text { (Downstream of tyrosine kinase } \\
\text { 5) (Protein dok-5) }\end{array}$ & 2.25 & 0.041 \\
\hline RGD1563073 & similar to SIGLEC-like 1 & 1.69 & 0.005 \\
\hline RGD1563982 & similar to F-box only protein 27 & 1.76 & 0.012 \\
\hline RGD1565316 & $\begin{array}{l}\text { similar to sphingomyelin phosphodiesterase } 3 \text {. neutral } \\
\text { membrane }\end{array}$ & 1.55 & 0.046 \\
\hline Rhbdf2* & rhomboid 5 homolog 2 (Drosophila) & 1.70 & 0.008 \\
\hline Rhoh* & ras homolog gene family. member $H$ & 1.52 & 0.016 \\
\hline Ripk3* & receptor-interacting serine-threonine kinase 3 & 1.69 & 0.009 \\
\hline Rnd1 & Rho family GTPase 1 & 2.28 & 0.007 \\
\hline Rpp38 & ribonuclease P/MRP 38 subunit (human) & 1.57 & 0.001 \\
\hline Sdc4* & syndecan 4 & 1.85 & 0.028 \\
\hline Sele* & selectin $\mathbf{E}$ & 1.67 & 0.008 \\
\hline Selp* & selectin $\mathbf{P}$ & 1.99 & 0.008 \\
\hline Serpine1 & serine (or cysteine) peptidase inhibitor. clade E. member 1 & 1.58 & 0.032 \\
\hline Slc39a14 & solute carrier family 39 (zinc transporter). member 14 & 1.60 & 0.002 \\
\hline Slfn3 & schlafen 3 & 1.65 & 0.046 \\
\hline Slitrk6 & SLIT and NTRK-like family. member 6 & -1.53 & 0.038 \\
\hline Snai1 & snail homolog 1 (Drosophila) & 1.52 & 0.006 \\
\hline Sned1 & sushi. nidogen and EGF-like domains 1 & 1.68 & 0.010 \\
\hline Socs1* & suppressor of cytokine signaling 1 & 1.73 & $\mathbf{0 . 0 2 7}$ \\
\hline Socs $3 *$ & suppressor of cytokine signaling 3 & 1.78 & 0.011 \\
\hline Star & steroidogenic acute regulatory protein & -1.67 & 0.041 \\
\hline Stx $11^{*}$ & syntaxin 11 & 1.54 & 0.019 \\
\hline Syt15 & synaptotagmin $\mathrm{XV}$ & -1.51 & 0.014 \\
\hline Tef & thyrotrophic embryonic factor & -1.70 & 0.001 \\
\hline Tfpi2 & tissue factor pathway inhibitor 2 & 2.26 & 0.001 \\
\hline TIr2* & toll-like receptor 2 & 1.69 & 0.011 \\
\hline Tmem2 & transmembrane protein 2 & 1.78 & 0.005 \\
\hline Tnfrsf12a* & tumor necrosis factor receptor superfamily. member 12a & 1.52 & 0.007 \\
\hline
\end{tabular}




\begin{tabular}{|l|l|c|l|}
\hline Trib1 & tribbles homolog 1 (Drosophila) & 1.56 & 0.040 \\
Trim30 & tripartite motif-containing 30 & 1.51 & 0.004 \\
Trmt61a & tRNA methyltransferase 61 homolog A (S. cerevisiae) & 1.53 & 0.011 \\
Tsc22d3* & TSC22 domain family. member 3 & -1.59 & 0.005 \\
Tubb3 & tubulin. beta 3 & 1.59 & 0.030 \\
Uap1 $*$ & UDP-N-acteylglucosamine pyrophosphorylase 1 & 2.05 & 0.003 \\
Uap1 $*$ & UDP-N-acteylglucosamine pyrophosphorylase 1 & 2.00 & 0.001 \\
Urb2 & URB2 ribosome biogenesis 2 homolog (S. cerevisiae) & 1.50 & 0.012 \\
Wdr89 & WD repeat domain 89 & 1.51 & 0.023 \\
Vegfa & vascular endothelial growth factor A & 1.68 & 0.017 \\
Zbp1 $*$ & Z-DNA binding protein 1 & 1.79 & 0.032 \\
Zfp185 & zinc finger protein 185 & 1.57 & 0.015 \\
\hline
\end{tabular}




\begin{tabular}{lccc}
\hline Molecular and cellular functions & p-value & Molecules involved & Specific functions \\
\hline Cellular movement & $<0.001$ & 47 & 34 \\
Cellular growth & $<0.001$ & 71 & 10 \\
Cellular development & $<0.001$ & 69 & 7 \\
Cell death and survival & $<0.001$ & 69 & 4 \\
Cell-to-cell signaling and interaction & $<0.001$ & 43 & 26 \\
\hline Cellular growth and proliferation & $<0.05$ & 37 & 0 \\
Cellular development & $<0.05$ & 29 & 0 \\
Cell-to-cell signaling and interaction & $<0.05$ & 22 & 0 \\
Carbohydrate metabolism & $<0.05$ & 11 & 0 \\
\hline
\end{tabular}




\begin{tabular}{|c|c|c|c|c|c|c|c|}
\hline Specific function & $\mathbf{A}$ & $\mathbf{B}$ & $\mathbf{C}$ & Specific function & $\mathbf{A}$ & B & $\mathbf{C}$ \\
\hline Activation of: & & & & Generation of: & & & \\
\hline antigen presenting cells & 2.9 & 11 & 5 & cells & 2.3 & 10 & 2 \\
\hline blood cells & 3.8 & 23 & 5 & lymphocytes & 2.1 & 8 & 2 \\
\hline cells & 3.8 & 31 & 5 & Invasion of: & & & \\
\hline central nervous system cells & 2.2 & 5 & 5 & cells & 3.4 & 21 & 1 \\
\hline dendritic cells & 2.1 & 6 & 5 & tumor cell lines & 3.0 & 14 & 1 \\
\hline leukocytes & 3.6 & 19 & 5 & Migration of: & & & \\
\hline macrophages & 2.4 & 7 & 5 & antigen presenting cells & 2.3 & 11 & 1 \\
\hline myeloid cells & 2.8 & 9 & 5 & cells & 3.8 & 44 & 1 \\
\hline phagocytes & 3.4 & 15 & 5 & mononuclear leukocytes & 2.2 & 17 & 1 \\
\hline Adhesion of: & & & & phagocytes & 2.6 & 16 & 1 \\
\hline immune cells & 2.9 & 15 & 5 & smooth muscle cells & 2.1 & 10 & 1 \\
\hline lymphocytes & 2.0 & 6 & 5 & tumor cell lines & 3.8 & 19 & 1 \\
\hline mononuclear leukocytes & 2.5 & 8 & 5 & Mobilization of: & & & \\
\hline vascular endothelial cells & 2.2 & 5 & 5 & blood cells & 2.2 & 6 & 1 \\
\hline Attraction of: & & & & leukocytes & 2.0 & 4 & 1 \\
\hline cells & 2.1 & 6 & 1,5 & Proliferation of: & & & \\
\hline leukocytes & 2.1 & 5 & 1,5 & breast cell lines & 2.4 & 6 & 2,3 \\
\hline Binding of: & & & & cells & 2.0 & 69 & 2 \\
\hline blood cells & 2.3 & 9 & 5 & connective tissue cells & 2.9 & 18 & 2 \\
\hline cells & 2.4 & 22 & 5 & ovarian cancer cell lines & 2.4 & 6 & 2,3 \\
\hline leukocytes & 2.1 & 8 & 5 & Recruitment of: & & & \\
\hline Cell movement of: & 3.5 & 47 & 1 & blood cells & 2.5 & 15 & 1,5 \\
\hline granulocytes & 2.1 & 15 & 1 & granulocytes & 2.4 & 11 & 1,5 \\
\hline leukocytes & 2.5 & 25 & 1 & mononuclear leukocytes & 2.2 & 6 & 1,5 \\
\hline lymphocytes & 2.4 & 14 & 1 & myeloid cells & 2.6 & 12 & 1,5 \\
\hline mast cells & 2.4 & 7 & 1 & Stimulation of: & & & \\
\hline mononuclear leukocytes & 2.0 & 22 & 1 & cells & 3.3 & 14 & 2,5 \\
\hline myeloid cells & 2.0 & 22 & 1 & leukocytes & 2.6 & 7 & 2,5 \\
\hline phagocytes & 2.2 & 23 & 1 & Others: & & & \\
\hline smooth muscle cells & 2.2 & 11 & 1 & Apoptosis of leukemia cell lines & 2.2 & 10 & 4 \\
\hline tumor cell lines & 3.6 & 23 & 1 & Cell survival & 2.7 & 33 & 4 \\
\hline Chemotaxis of: & & & & Cell viability & 2.5 & 31 & 4 \\
\hline antigen presenting cells & 2.2 & 9 & 1 & Viability of tumor cell lines & 2.9 & 17 & 4 \\
\hline cells & 3.3 & 23 & 1 & Expansion of cells & 2.2 & 11 & 2 \\
\hline leukocytes & 2.7 & 18 & 1 & Formation of cells & 3.2 & 16 & 2 \\
\hline myeloid cells & 2.3 & 16 & 1 & Interaction of leukocytes & 2.4 & 6 & 5 \\
\hline phagocytes & 2.9 & 17 & 1 & Leukocyte migration & 3.1 & 29 & 1 \\
\hline Differentiation of: & & & & Localization of cells & 2.0 & 6 & 1 \\
\hline blood cells & 2.6 & 22 & 3 & Lymphocyte migration & 2.2 & 13 & 1 \\
\hline cells & 3.1 & 43 & 3 & Phagocytosis of cells & 2.1 & 12 & 5 \\
\hline connective tissue cells & 3.0 & 17 & 3 & & & & \\
\hline leukocytes & 2.6 & 20 & 3 & & & & \\
\hline osteoclasts & 2.6 & 11 & 3 & & & & \\
\hline
\end{tabular}




\begin{tabular}{|c|c|c|c|}
\hline \multirow{6}{*}{$\stackrel{\infty}{\vec{D}}$} & Upstream regulators & p-value & Predicted activation \\
\hline & IL1B & $<0.001$ & Activated \\
\hline & IFNG & $<0.001$ & Activated \\
\hline & TNF & $<0.001$ & Activated \\
\hline & lipopolysaccharide & $<0.001$ & Activated \\
\hline & NFkB (complex) & $<0.001$ & Activated \\
\hline \multirow{5}{*}{$\frac{ \pm}{\Delta}$} & IL $1 \mathrm{~B}$ & $<0.001$ & Activated \\
\hline & TLR9 & $<0.001$ & \\
\hline & U0126 & $<0.001$ & \\
\hline & IFNAR1 & $<0.001$ & \\
\hline & poly rl:rC-RNA & $<0.001$ & Activated \\
\hline
\end{tabular}




\begin{tabular}{|c|c|c|c|}
\hline Gene & Gene name & FC & $\mathbf{p}$ \\
\hline $\mathrm{A} 2 \mathrm{~m} *$ & alpha-2-macroglobulin & -1.73 & 0.004 \\
\hline Adfp & adipose differentiation related protein & -1.51 & 0.021 \\
\hline Apold1 & apolipoprotein $\mathrm{L}$ domain containing 1 & 1.59 & 0.001 \\
\hline Atf3* & activating transcription factor 3 & 1.65 & 0.001 \\
\hline Btg2 & BTG family. member 2 & 2.30 & 0.000 \\
\hline Ccl7* & chemokine (C-C motif) ligand 7 & 1.52 & $\mathbf{0 . 0 3 4}$ \\
\hline Chodl & chondrolectin & 1.77 & 0.037 \\
\hline Cxcl13* & chemokine (C-X-C motif) ligand 13 & -1.63 & 0.044 \\
\hline Dkk2 & dickkopf homolog 2 (Xenopus laevis) & 1.54 & 0.013 \\
\hline Dusp1 & dual specificity phosphatase 1 & 1.56 & 0.001 \\
\hline Egr1 & early growth response 1 & 1.63 & 0.014 \\
\hline Egr3* & early growth response 3 & 1.78 & 0.018 \\
\hline Elmod1* & ELMO/CED-12 domain containing 1 & 1.64 & 0.017 \\
\hline Emilin3 & elastin microfibril interfacer 3 & 1.53 & 0.002 \\
\hline Fos & FBJ osteosarcoma oncogene & 2.24 & $\mathbf{0 . 0 3 3}$ \\
\hline Gadd $45 g^{*}$ & growth arrest and DNA-damage-inducible. gamma & 1.74 & 0.000 \\
\hline Hmgcs2 & 3-hydroxy-3-methylglutaryl-Coenzyme A synthase 2 (mitochondrial) & -2.23 & 0.025 \\
\hline Hrasls & HRAS-like suppressor & 1.52 & 0.019 \\
\hline Ier2 & immediate early response 2 & 2.20 & 0.000 \\
\hline Ier3* & immediate early response 3 & 1.66 & 0.009 \\
\hline Il10* & interleukin 10 & 1.64 & 0.020 \\
\hline Il1b* & interleukin 1 beta & 2.18 & 0.001 \\
\hline Il1rl1* & interleukin 1 receptor-like 1 & -1.75 & 0.003 \\
\hline Il6* & interleukin 6 & 2.20 & $\mathbf{0 . 0 3 8}$ \\
\hline Itga $2 *$ & integrin. alpha 2 & 1.53 & 0.047 \\
\hline Junb* & jun B proto-oncogene & 1.63 & 0.002 \\
\hline Kcnma1 & $\begin{array}{l}\text { potassium large conductance calcium-activated channel. subfamily M. } \\
\text { alpha member } 1\end{array}$ & 1.56 & 0.002 \\
\hline Kera & keratocan & 1.79 & 0.027 \\
\hline Kif26b & $\begin{array}{l}\text { kinesin family member } 26 \mathrm{~B} \\
\text { similar to High mobility group protein } 1 \text { (HMG-1) (High mobility }\end{array}$ & -1.64 & 0.017 \\
\hline LOC690521 & group protein $\mathrm{B} 1$ ) & -1.57 & 0.020 \\
\hline Mir24-2 & microRNA mir-24-2 & 1.50 & 0.036 \\
\hline Mir27a & microRNA mir-27a & 1.82 & 0.012 \\
\hline Msr1* & macrophage scavenger receptor 1 & -1.65 & 0.001 \\
\hline $\mathrm{Mx} 2 *$ & myxovirus (influenza virus) resistance 2 & 3.07 & 0.003 \\
\hline ND6 & NADH dehydrogenase subunit 6 & -1.64 & 0.024 \\
\hline Nfkbiz* & $\begin{array}{l}\text { nuclear factor of kappa light polypeptide gene enhancer in B-cells } \\
\text { inhibitor. zeta }\end{array}$ & 1.56 & 0.000 \\
\hline $\mathrm{Nr} 4 \mathrm{a} 1 *$ & nuclear receptor subfamily 4. group A. member 1 & 3.81 & 0.005 \\
\hline $\mathrm{Nr} 4 \mathrm{a} 2 *$ & nuclear receptor subfamily 4. group A. member 2 & 2.61 & 0.001 \\
\hline $\mathrm{Nr} 4 \mathrm{a} 3 *$ & nuclear receptor subfamily 4 . group A. member 3 & 3.54 & 0.003 \\
\hline Olr1058 & olfactory receptor 1058 & 1.86 & 0.005 \\
\hline Oxtr & oxytocin receptor & -1.64 & 0.019 \\
\hline Prox $1 *$ & prospero homeobox 1 & 1.73 & 0.004 \\
\hline
\end{tabular}




\begin{tabular}{|l|l|c|c|}
\hline Ptgs2 $*$ & prostaglandin-endoperoxide synthase 2 (COX-2) & $\mathbf{1 . 8 5}$ & $\mathbf{0 . 0 1 1}$ \\
Retnlg & resistin-like gamma & -1.56 & 0.010 \\
Rgs1* & regulator of G-protein signaling 1 & $\mathbf{1 . 6 0}$ & $\mathbf{0 . 0 1 7}$ \\
Rgs2 $*$ & regulator of G-protein signaling 2 & $\mathbf{1 . 6 9}$ & $\mathbf{0 . 0 0 0}$ \\
Rgs6 & regulator of G-protein signaling 6 & $\mathbf{1 . 5 3}$ & $\mathbf{0 . 0 0 1}$ \\
Robo2 & roundabout. axon guidance receptor. homolog 2 (Drosophila) & 1.71 & 0.048 \\
RT1-CE2* & RT1 class I. locus CE2 & -1.52 & 0.046 \\
RT1-CE5* & RT1 class I. locus CE5 & -1.58 & 0.045 \\
Scnn1b & sodium channel. nonvoltage-gated 1. beta & 1.54 & 0.026 \\
Snrpd1 & small nuclear ribonucleoprotein D1 & 2.02 & 0.011 \\
Xcr1* & chemokine (C motif) receptor 1 & $\mathbf{1 . 6 4}$ & $\mathbf{0 . 0 0 3}$ \\
\hline
\end{tabular}




\begin{tabular}{|c|c|c|c|}
\hline Gene & Gene name & FC & $\mathbf{p}$ \\
\hline Actg2 & actin. gamma 2. smooth muscle. enteric & -1.71 & 0.023 \\
\hline Adamts4* & ADAM metallopeptidase with thrombospondin type 1 motif. 4 & 1.60 & 0.006 \\
\hline Arntl & aryl hydrocarbon receptor nuclear translocator-like & 1.58 & 0.005 \\
\hline Bmp5 & bone morphogenetic protein 5 & -1.66 & 0.006 \\
\hline C6* & complement component 6 & -1.83 & 0.005 \\
\hline Ccl3* & chemokine (C-C motif) ligand 3 & -1.66 & 0.022 \\
\hline Ccl6* & chemokine (C-C motif) ligand 6 & -1.63 & 0.041 \\
\hline $\mathrm{Cd} 180 *$ & CD180 molecule & -1.62 & 0.026 \\
\hline Cebpb* & CCAAT/enhancer binding protein $(\mathrm{C} / \mathrm{EBP})$. beta & 1.52 & 0.003 \\
\hline Clk1 & CDC-like kinase 1 & 1.58 & 0.010 \\
\hline Clk4 & CDC like kinase 4 & 1.51 & 0.002 \\
\hline Crabp2 & cellular retinoic acid binding protein 2 & 1.94 & 0.019 \\
\hline Cyp26b1 & cytochrome P450. family 26 . subfamily b. polypeptide 1 & 1.78 & 0.004 \\
\hline Dact1 & dapper. antagonist of beta-catenin. homolog 1 (Xenopus laevis) & -1.64 & 0.000 \\
\hline Dio3 & deiodinase. iodothyronine. type III & 1.67 & 0.017 \\
\hline Elmod1* & ELMO/CED-12 domain containing 1 & 1.71 & 0.007 \\
\hline Epha7 & Eph receptor A7 & -1.66 & 0.000 \\
\hline Fkbp5* & FK506 binding protein 5 & 1.98 & 0.005 \\
\hline Freq & frequenin homolog (Drosophila) & 1.65 & 0.003 \\
\hline Fzd8* & frizzled homolog 8 (Drosophila) & -1.58 & 0.007 \\
\hline Gabre & gamma-aminobutyric acid (GABA) A receptor. epsilon & 1.67 & 0.023 \\
\hline Gata6 & GATA binding protein 6 & -1.69 & 0.003 \\
\hline Gbp5 & guanylate binding protein 5 & -1.50 & 0.004 \\
\hline Gfpt2* & glutamine-fructose-6-phosphate transaminase 2 & 1.62 & 0.042 \\
\hline Gnat1 & guanine nucleotide binding protein. alpha transducing 1 & 2.02 & 0.008 \\
\hline Gpr18 & G protein-coupled receptor 18 & -1.57 & 0.001 \\
\hline Gpr34* & G protein-coupled receptor 34 & -1.83 & 0.002 \\
\hline Has $1^{*}$ & hyaluronan synthase 1 & 2.18 & 0.026 \\
\hline Hbegf* & heparin-binding EGF-like growth factor & 1.74 & 0.039 \\
\hline Heatr3* & HEAT repeat containing 3 & 1.52 & 0.014 \\
\hline Hoxb6 & homeo box B6 & 1.50 & 0.029 \\
\hline Hsph1 & heat shock $105 \mathrm{kDa} / 110 \mathrm{kDa}$ protein 1 & 1.68 & 0.003 \\
\hline Ifit $3 *$ & interferon-induced protein with tetratricopeptide repeats 3 & -1.67 & 0.001 \\
\hline
\end{tabular}




\begin{tabular}{|c|c|c|c|}
\hline Il1b* & interleukin 1 beta & 1.63 & 0.012 \\
\hline Kbtbd8 & kelch repeat and BTB (POZ) domain containing 8 & 1.50 & 0.009 \\
\hline Kif26b & kinesin family member $26 \mathrm{~B}$ & -1.54 & 0.049 \\
\hline Lilra5* & $\begin{array}{l}\text { leukocyte immunoglobulin-like receptor. subfamily A (with TM } \\
\text { domain). member } 5\end{array}$ & -2.24 & $\mathbf{0 . 0 3 0}$ \\
\hline Lins & lines homolog (Drosophila) & 1.51 & 0.017 \\
\hline LOC100365768 & rCG43589-like & 1.62 & 0.032 \\
\hline LOC686042 & hypothetical protein LOC686042 & 1.59 & 0.046 \\
\hline LOC686781 & similar to NFkB interacting protein 1 & 1.51 & 0.001 \\
\hline LOC690521 & $\begin{array}{l}\text { similar to High mobility group protein } 1 \text { (HMG-1) (High mobility } \\
\text { group protein B1) }\end{array}$ & -1.96 & 0.001 \\
\hline Lonrf2 & LON peptidase $\mathrm{N}$-terminal domain and ring finger 2 & 1.51 & 0.016 \\
\hline Mex3b & mex3 homolog B (C. elegans) & -1.71 & 0.001 \\
\hline MGC108823 & similar to interferon-inducible GTPase & -1.57 & 0.002 \\
\hline Mir134 & microRNA mir-134 & 1.50 & 0.043 \\
\hline Mir154 & microRNA mir-154 & 1.67 & 0.027 \\
\hline Mir22 & microRNA mir-22 & -1.55 & 0.009 \\
\hline Mir300 & microRNA mir-300 & 1.82 & 0.031 \\
\hline Mir323 & microRNA mir-323 & 1.65 & 0.046 \\
\hline Mir369 & microRNA mir-369 & 1.53 & 0.046 \\
\hline Mir380 & microRNA mir-380 & 1.54 & 0.048 \\
\hline Mir382 & microRNA mir-382 & 1.77 & 0.039 \\
\hline Mir410 & microRNA mir-410 & 2.22 & 0.002 \\
\hline Mir411 & microRNA mir-411 & 1.60 & 0.011 \\
\hline Mir485 & microRNA mir-485 & 1.67 & 0.047 \\
\hline Mir495 & microRNA mir-495 & 1.67 & 0.013 \\
\hline Nedd9 & neural precursor cell expressed. developmentally down-regulated 9 & -1.59 & 0.003 \\
\hline Nr1d $1 *$ & nuclear receptor subfamily 1 . group D. member 1 & -1.99 & 0.000 \\
\hline $\mathrm{Nr} 4 \mathrm{a} 3$ & nuclear receptor subfamily 4 . group A. member 3 & 3.06 & 0.027 \\
\hline Oxtr & oxytocin receptor & -2.16 & 0.011 \\
\hline $\mathrm{P} 2 \mathrm{rx} 1$ & purinergic receptor $\mathrm{P} 2 \mathrm{X}$. ligand-gated ion channel. 1 & -1.55 & 0.025 \\
\hline Phlda1 & pleckstrin homology-like domain. family A. member 1 & 1.60 & 0.000 \\
\hline Phtf2 & putative homeodomain transcription factor 2 & 1.56 & 0.005 \\
\hline Pik3ip1 & phosphoinositide-3-kinase interacting protein 1 - & -1.61 & 0.001 \\
\hline Pop1 & cerevisiae) & 1.52 & 0.010 \\
\hline $\begin{array}{l}\text { Ppan } \\
\text { Pprc1 }\end{array}$ & $\begin{array}{l}\text { peter pan homolog (Drosophila) } \\
\text { peroxisome proliferator-activated receptor gamma. coactivator- } \\
\text { related } 1\end{array}$ & 1.51 & $\begin{array}{l}0.002 \\
0.001\end{array}$ \\
\hline
\end{tabular}




\begin{tabular}{|c|c|c|c|}
\hline PVR* & poliovirus receptor & 1.52 & 0.001 \\
\hline Rasgrf1 & RAS protein-specific guanine nucleotide-releasing factor 1 & 1.60 & 0.001 \\
\hline Retnlg & resistin-like gamma & -1.55 & 0.003 \\
\hline RGD1305184 & similar to CDNA sequence $\mathrm{BC} 023105$ & -1.81 & 0.000 \\
\hline RGD1563365 & $\begin{array}{l}\text { similar to DNA segment. Chr 10. Wayne State University } 102 . \\
\text { expressed }\end{array}$ & 1.56 & 0.009 \\
\hline RGD1564171 & RGD1564171 & 1.60 & 0.043 \\
\hline Ripk3* & receptor-interacting serine-threonine kinase 3 & 1.71 & 0.005 \\
\hline Rtp4 & receptor (chemosensory) transporter protein 4 & -1.70 & 0.035 \\
\hline Sbno2* & strawberry notch homolog 2 (Drosophila) & $\mathbf{1 . 5 0}$ & 0.018 \\
\hline $\mathrm{Sdc} 4 *$ & syndecan 4 & 1.52 & 0.005 \\
\hline Siglec10* & sialic acid binding Ig-like lectin 10 & -1.58 & 0.008 \\
\hline Slitrk6 & SLIT and NTRK-like family. member 6 & -1.67 & 0.014 \\
\hline Snai1 & snail homolog 1 (Drosophila) & 1.62 & 0.013 \\
\hline Snrpd1 & small nuclear ribonucleoprotein D1 & 1.77 & 0.026 \\
\hline Socs1* & suppressor of cytokine signaling 1 & 1.55 & 0.021 \\
\hline Svs5 & seminal vesicle secretory protein 5 & 1.51 & 0.011 \\
\hline Tfpi2 & tissue factor pathway inhibitor 2 & 2.10 & 0.043 \\
\hline Trim46 & tripartite motif-containing 46 & 1.58 & 0.044 \\
\hline Uap1* & UDP-N-acteylglucosamine pyrophosphorylase 1 & 1.57 & 0.010 \\
\hline Uap1* & UDP-N-acteylglucosamine pyrophosphorylase 1 & 1.51 & 0.021 \\
\hline Usp18* & ubiquitin specific peptidase 18 & -1.53 & 0.010 \\
\hline Zbtb11 & zinc finger and BTB domain containing 11 & 1.67 & 0.010 \\
\hline Zfp458 & zinc finger protein 458 & 1.56 & 0.009 \\
\hline
\end{tabular}




\begin{tabular}{|c|c|c|c|c|c|c|}
\hline \multirow[b]{2}{*}{ Gene } & \multirow[b]{2}{*}{ Gene name } & \multicolumn{2}{|c|}{ Day 3} & \multicolumn{2}{|c|}{ Day 14} & \multirow[b]{2}{*}{ Biological process } \\
\hline & & FC & $\mathbf{p}$ & FC & $\mathbf{p}$ & \\
\hline ADAMTS4 & ADAM metallopeptidase 4 & 2.3 & $<0.001$ & 1.6 & $<0.01$ & I, TI\&H, EM, M \\
\hline CEBPB & CCAAT/enhancer binding protein (C/EBP), beta & 1.6 & $<0.05$ & 1.5 & $<0.01$ & I \\
\hline GFPT2 & Glutamine-fructose-6-phosphate transaminase 2 & 1.8 & $<0.01$ & 1.6 & $<0.05$ & I, TI\&H, EM, M \\
\hline GNAT1 & Guanine nucleotide binding protein, alpha transducing 1 & 1.9 & $<0.05$ & 2.0 & $<0.01$ & \\
\hline GPR34 & $\mathrm{G}$ protein-coupled receptor 34 & -1.5 & $<0.05$ & -1.8 & $<0.01$ & $\mathrm{I}, \mathrm{M}$ \\
\hline HAS1 & Hyaluronan synthase 1 & 3.2 & $<0.05$ & 2.1 & $<0.05$ & I, TI\&H, EM, M \\
\hline HEATR3 & HEAT repeat containing 3 & 1.6 & $<0.01$ & 1.5 & $<0.05$ & I, TI\&H \\
\hline HSPH1 & Heat shock $105 \mathrm{kDa} / 110 \mathrm{kDa}$ protein 1 & 1.7 & $<0.01$ & 1.7 & $<0.01$ & $\mathrm{TI} \& \mathrm{H}$ \\
\hline MIR323 & MicroRNA mir-323 & 2.1 & $<0.05$ & 1.7 & $<0.05$ & \\
\hline NR1D1 & Nuclear receptor subfamily 1 , group $D$, member 1 & -2.8 & $<0.001$ & -2.0 & $<0.001$ & I \\
\hline RIPK3 & Receptor-interacting serine-threonine kinase 3 & 1.6 & $<0.01$ & 1.7 & $<0.001$ & I \\
\hline SBNO2 & Strawberry notch homolog 2 & 1.5 & $<0.01$ & 1.5 & $<0.05$ & I \\
\hline $\mathrm{SDC} 4$ & Syndecan 4 & 1.8 & $<0.05$ & 1.5 & $<0.01$ & I, TI\&H, M, P \\
\hline SNAI1 & Snail homolog 1 (Drosophila) & 1.5 & $<0.01$ & 1.6 & $<0.05$ & $\mathrm{P}$ \\
\hline SOCS1 & Supressor of cytokine signaling 1 & 1.7 & $<0.05$ & 1.5 & $<0.05$ & I \\
\hline TFPI2 & Tissue factor pathway inhibitor 2 & 2.2 & $<0.01$ & 2.1 & $<0.05$ & $\mathrm{EM}$ \\
\hline TNFRSF $12 \mathrm{~A}$ & Tumor necrosis factor receptor superfamily, member $12 \mathrm{a}$ & 1.5 & $<0.01$ & 1.5 & $<0.01$ & I, TI\&H, EM, M, P \\
\hline UAP1 & UDP-N-acetylglucosamine pyrophosphorylase 1 & 2.1 & $<0.01$ & 1.6 & $<0.01$ & I, TI\&H, EM, M \\
\hline
\end{tabular}




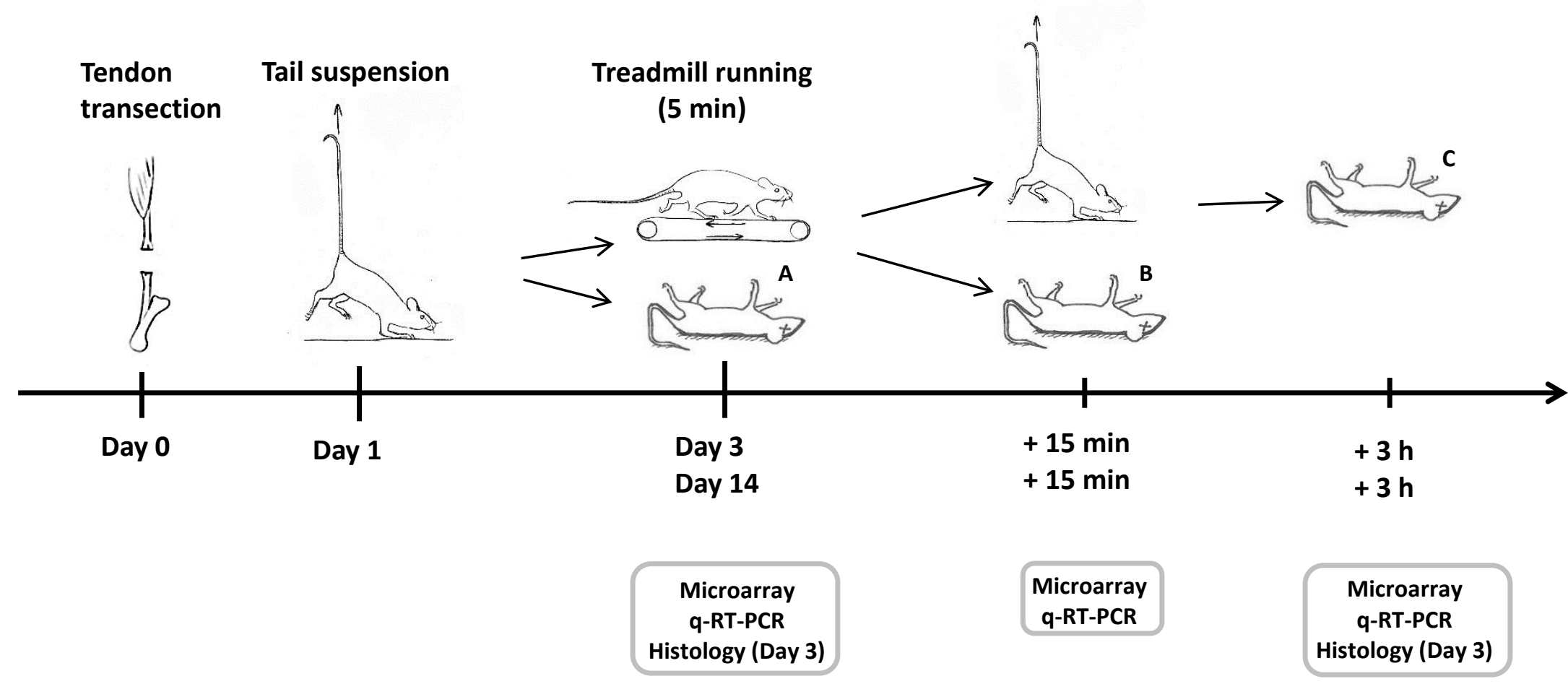




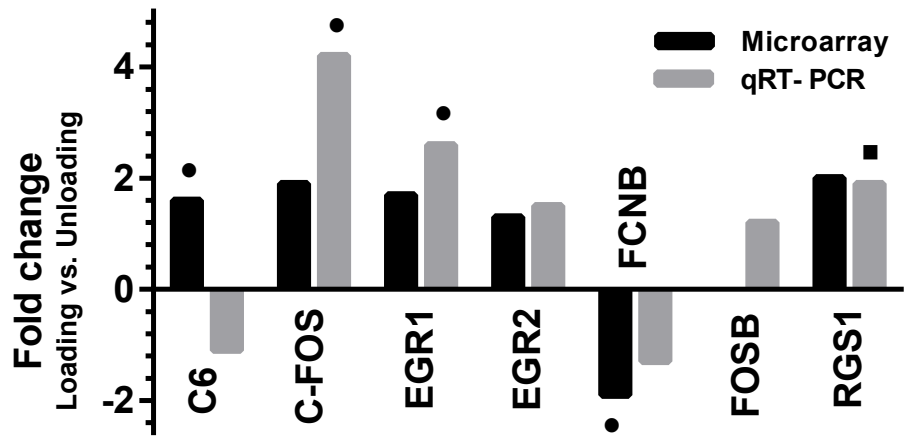




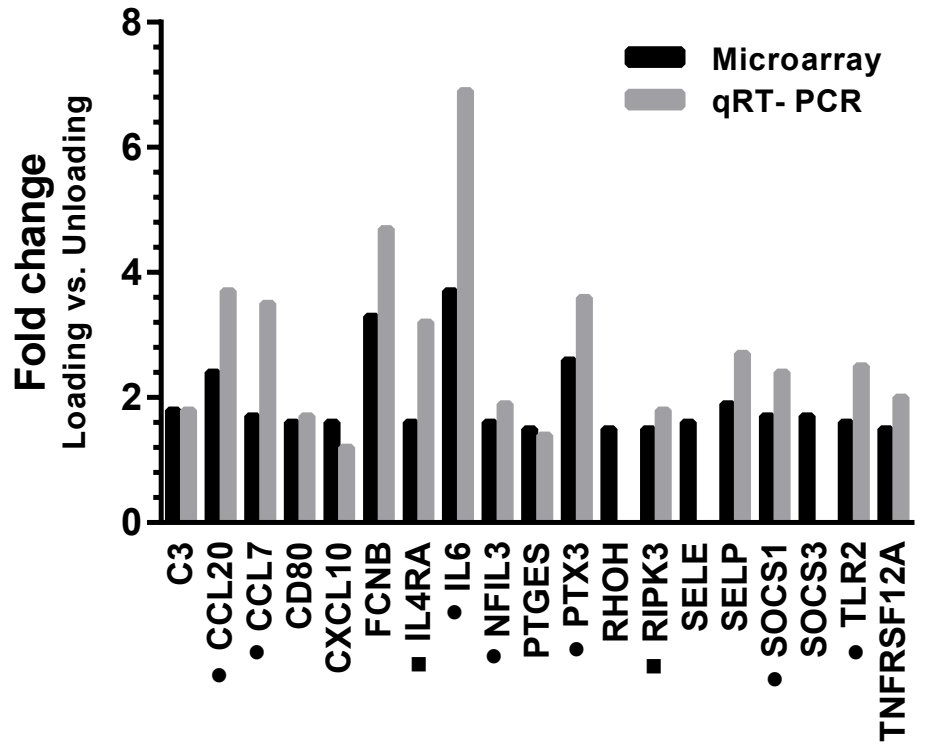




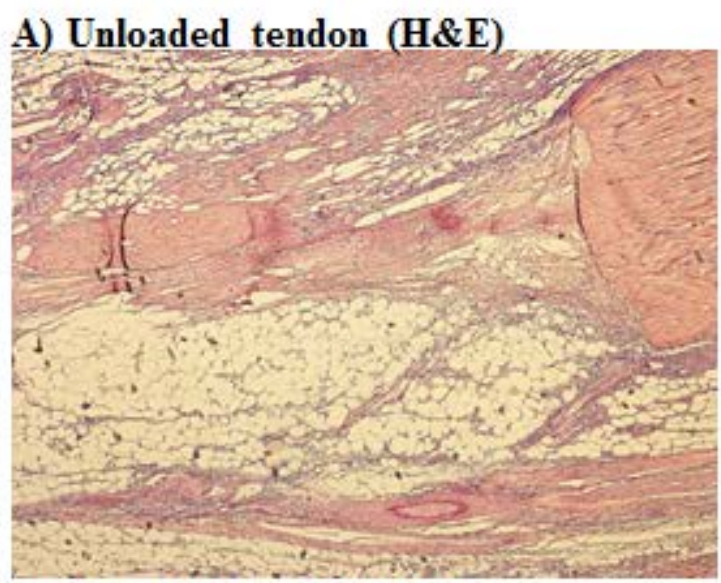

C) Unloaded tendon (CD45)

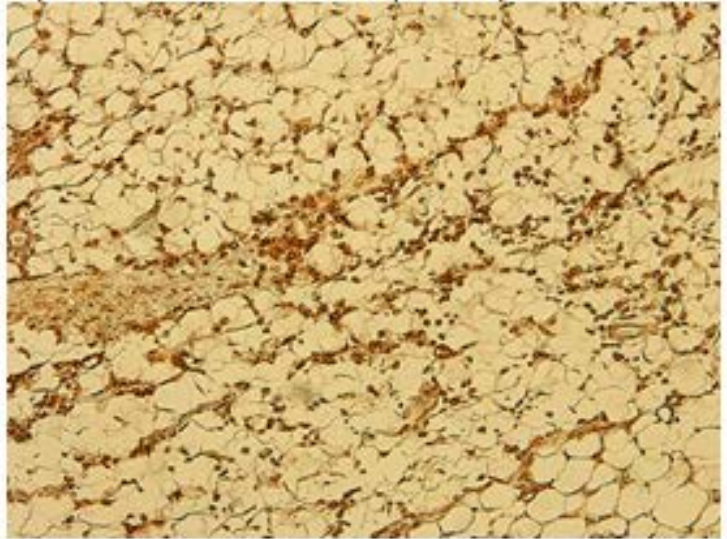

B) Loaded tendon (CD68)

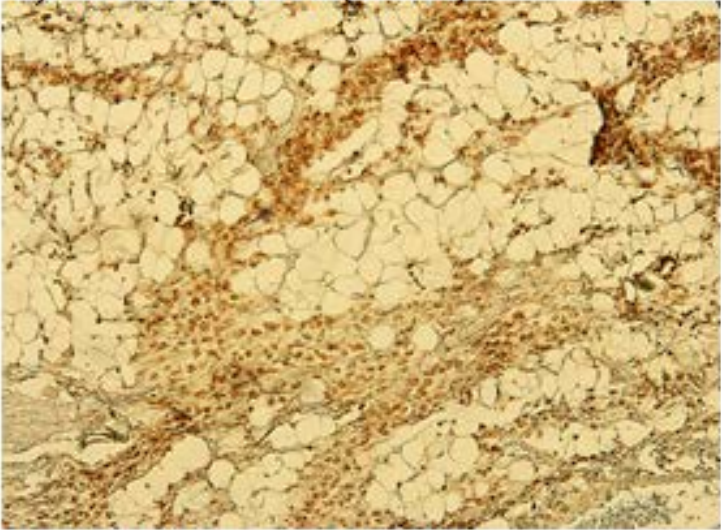

D) Loaded tendon (CD45)

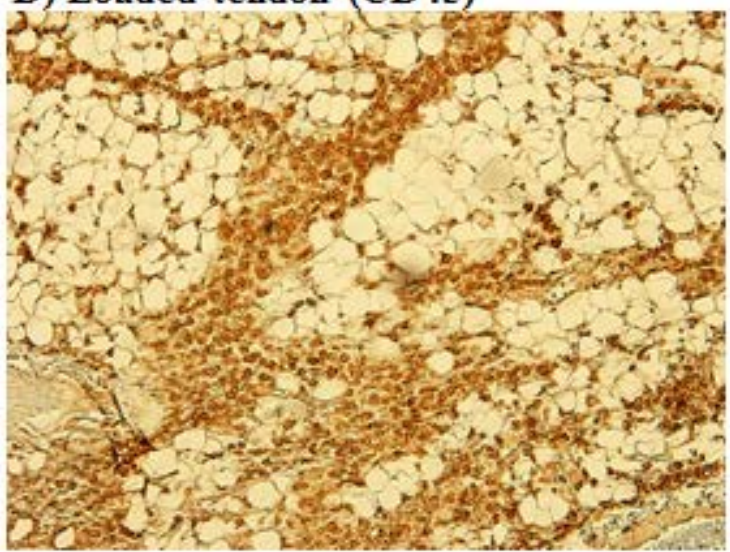

E

\begin{tabular}{|c|c|c|c|}
\hline & ID & CD45 & CD68 \\
\hline \multirow{4}{*}{ 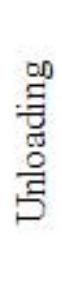 } & A & 3 & 4 \\
\hline & B & 4.5 & 8.5 \\
\hline & $\mathrm{C}$ & 5 & 9 \\
\hline & D & 7 & 7.5 \\
\hline \multirow{4}{*}{ 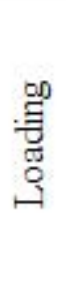 } & $\mathrm{E}$ & 7 & 3.5 \\
\hline & F & 8 & 8.5 \\
\hline & $\mathrm{G}$ & 8 & 4 \\
\hline & $\mathrm{H}$ & 9 & 9 \\
\hline
\end{tabular}




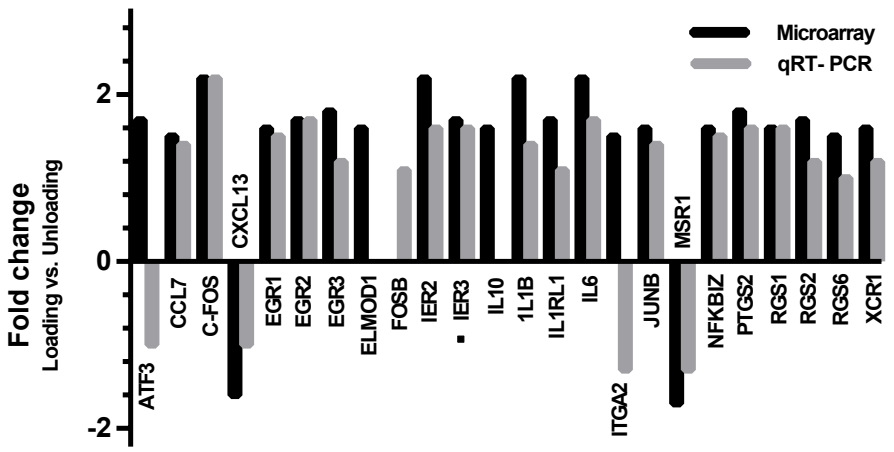




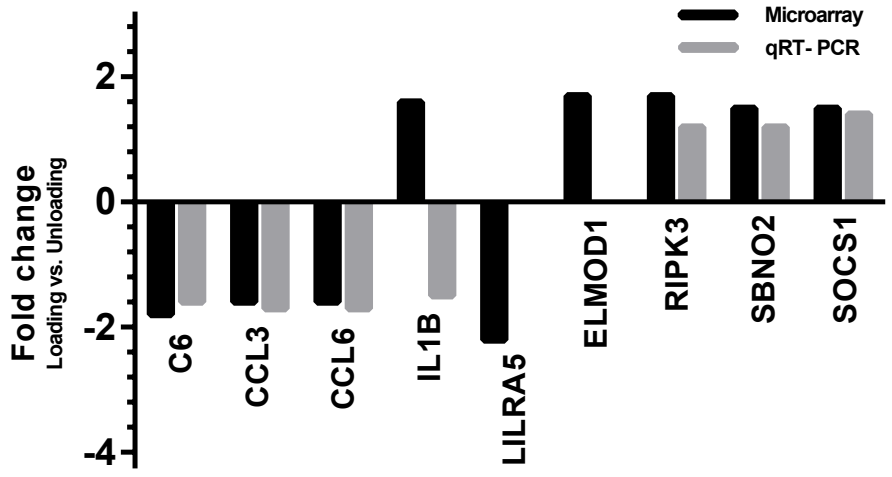

